\title{
Changes in Caribbean surface hydrography during the Pliocene shoaling of the Central American Seaway
}

\author{
Silke Steph, ${ }^{1,2}$ Ralf Tiedemann, ${ }^{3}$ Matthias Prange, ${ }^{4}$ Jeroen Groeneveld, ${ }^{1,5}$ \\ Dirk Nürnberg, ${ }^{1}$ Lars Reuning, ${ }^{1,6}$ Michael Schulz, ${ }^{4}$ and Gerald H. Haug ${ }^{7}$
}

Received 15 September 2004; revised 8 June 2006; accepted 17 August 2006; published 28 December 2006.

[1] Pliocene $\delta^{18} \mathrm{O}$ records of shallow and deep dwelling planktonic foraminifers from the Caribbean (Ocean Drilling Program sites 999 and 1000), the tropical east Pacific (sites 1241 and 851), and the Atlantic (site 925, Ceara Rise, and site 1006, western Great Bahama Bank) were used to examine Atlantic-Caribbean-Pacific atmospheric and oceanic linkages associated with the progressive closure of the Central American Seaway (5.5-3 Ma). Comparisons indicate the development of an inner-Caribbean salinity gradient in the mixed layer and salinity changes on precessional periodicities after 4.4 Ma (site 1000), when the Pacific-Caribbean throughflow became significantly restricted. The high-amplitude variability in salinity is also observed at site 1006, monitoring the Caribbean outflow into the Atlantic. Comparisons of Caribbean and Atlantic planktonic $\delta^{18} \mathrm{O}$ records suggest the North Atlantic subtropical gyre as a major source for high-salinity surface waters. Precession-induced variations in the volume transport of Pacific surface water masses through the Panamanian Seaway are considered a main factor to explain the Caribbean salinity minima. Results from a coupled climate model point to changes in the El Niño-Southern Oscillation state as a potential trigger for changes in the amount of Pacific inflow into the Caribbean.

Citation: Steph, S., R. Tiedemann, M. Prange, J. Groeneveld, D. Nürnberg, L. Reuning, M. Schulz, and G. H. Haug (2006), Changes in Caribbean surface hydrography during the Pliocene shoaling of the Central American Seaway, Paleoceanography, 21, PA4221, doi:10.1029/2004PA001092.

\section{Introduction}

[2] The closure of the Central American Seaway (CAS) at about 2.7 Ma and the intensification of Northern Hemisphere glaciation $(\mathrm{NHG})$ since $\sim 3$ Ma played a major role in the modification of Pliocene climate and oceanography. Closure-induced changes in global thermohaline circulation have been considered to be the cause either for the onset [Berggren and Hollister, 1974], for the delay [Berger and Wefer, 1996], or for setting the preconditions for $\mathrm{NHG}$ [Haug and Tiedemann, 1998; Driscoll and Haug, 1998]. While the link between closure and climate is still a matter of debate, paleoceanographic studies suggest a close link between the formation of the isthmus and major oceanographic changes during the early Pliocene (4.7-4.2 Ma), when the shoaling of the Panamanian sill reached a critical

\footnotetext{
${ }^{1}$ Leibniz Institute of Marine Sciences, IFM-GEOMAR, Kiel, Germany. ${ }^{2}$ Now at Alfred Wegener Institute for Polar and Marine Research, Bremerhaven, Germany.

${ }^{3}$ Alfred Wegener Institute for Polar and Marine Research, Bremerhaven, Germany.

${ }^{4}$ Deutsche Forschungsgemeinschaft Research Center Ocean Margins and Department of Geosciences, University of Bremen, Bremen, Germany.

${ }^{5}$ Now at Deutsche Forschungsgemeinschaft Research Center Ocean Margins and Department of Geosciences, University of Bremen, Bremen, Germany.

${ }^{6}$ Now at Institute of Geology, Rheinisch-Westfälische Technische Hochschule Aachen, Aachen, Germany.

${ }^{7}$ GeoForschungsZentrum Potsdam, Potsdam, Germany.

Copyright 2006 by the American Geophysical Union. 0883-8305/06/2004PA001092\$12.00
}

threshold for upper ocean water mass exchange [Keigwin, 1982; Haug et al., 2001a]. Restricted exchange of surface water led to the establishment of the modern Atlantic/Pacific salinity contrast that may be linked to atmospheric net freshwater transport from the tropical Atlantic and Caribbean into the equatorial east Pacific [e.g., Broecker and Denton, 1989; Jousaumme et al., 1986]. In addition, results from General Circulation Models and paleoceanographic studies suggest a reorganization of equatorial Pacific surface circulation, and an increased volume transport of heat and salt into the North Atlantic via an intensified Gulf Stream, favoring North Atlantic Deep Water (NADW) formation and Atlantic carbonate preservation [Maier-Reimer et al., 1990; Farrell et al., 1995; Tiedemann and Franz, 1997; Billups et al., 1997; Cannariato and Ravelo, 1997; Mikolajewicz and Crowley, 1997; Haug and Tiedemann, 1998; Billups et al., 1999; Haug et al., 2001a; Prange and Schulz, 2004].

[3] Here we present a high-resolution planktonic foraminiferal oxygen isotope record for Globigerinoides sacculifer $\left(\delta^{18} \mathrm{O}_{\text {sac }}\right)$ from Caribbean ODP site 1000 located at Pedro Channel on the Northern Nicaragua Rise. This $\delta^{18} \mathrm{O}_{\text {sac }}$ record spans the time interval from 5.6-3 Ma and is compared with the recently published planktonic $\delta^{18} \mathrm{O}_{\text {sac }}$ record from ODP site 999 [Haug et al., 2001a], which is positioned farther south and thus closer to the Pliocene gateway region. Haug et al. [2001a] attempted to assess closure-related changes in Caribbean sea surface salinity (SSS) by comparing planktonic $\delta^{18} \mathrm{O}_{\text {sac }}$ records from Caribbean site 999 and equatorial east Pacific site 851. They interpreted the divergence between both records to reflect a 
Caribbean SSS increase of 1 salinity unit since $4.2 \mathrm{Ma}$, assuming no major change in sea surface temperature (SST) that would in turn affect the SSS estimate. Our new record from site 1000 considers changes in SST for the first time and provides insight into Pliocene latitudinal gradients in Caribbean surface water hydrography. Major differences in Caribbean SSS developed after 4.7-4.2 Ma, suggesting strong local changes in addition to the general SSS increase. To further assess Caribbean surface water mass exchange with the Pacific and the Atlantic, we compare the Caribbean records with $\delta^{18} \mathrm{O}_{\text {sac }}$ records from the tropical east Pacific (site 1241) and the Atlantic (sites 925, 1006). In addition, we present oxygen isotope records for the deep dwelling planktonic foraminifera Globorotalia crassaformis $\left(\delta^{18} \mathrm{O}_{\text {cras }}\right)$ for Caribbean sites 999,1000 , and Pacific site 1241 to examine the exchange of subsurface water masses ( $400 \mathrm{~m}$ water depth) during the time interval from 3.7 to $4 \mathrm{Ma}$. Forcing mechanisms that might have controlled the Pliocene history of Caribbean SSS are discussed, considering long-term tectonic feedbacks along with orbital-scale changes in atmosphere-upper ocean interactions and insolation. In order to assess the significance of these mechanisms, we analyze the results of a climate model experiment with open CAS.

\section{Modern Caribbean Oceanography}

[4] Being a major source region for the Gulf Stream, the Caribbean Sea plays an important role in the net export of heat and salt into high northern latitudes. Today, the upper water column in the southern part of the Caribbean is composed of relatively fresh Caribbean Water $(\mathrm{CW}, 0-80 \mathrm{~m})$ and highsalinity Subtropical Under Water (SUW) $(80-180 \mathrm{~m})$, which forms the permanent Caribbean thermocline [Wüst, 1964]. The CW represents a mixture of the Amazon and Orinoco River outflow and equatorial Atlantic surface water which enters the Caribbean mainly via the Guyana Current through the Lesser Antilles Passages. The salinity-enriched SUW, formed by excess evaporation in the subtropical gyre, enters the Caribbean mainly via the North Equatorial Current through the Greater Antilles Passages (Windward and Mona Passage) [Wüst, 1964; Johns et al., 2002]. These water masses form the Caribbean Current that passes the Yucatan Channel and the Florida Straits, where it merges with the Antilles Current to form the northward flowing Western Boundary Current (Figure 1).

[5] The average flow through the Caribbean is estimated to be 20-30 Sv ( $1 \mathrm{~Sv}=1$ Sverdrup $\left.=10^{6} \mathrm{~m}^{3} \mathrm{~s}^{-1}\right)$ [e.g., Müller-Karger et al., 1989; Johns et al., 2002]. Numerical models [e.g., Johns et al., 2002] suggest that the volume of shallow Atlantic water masses transported into the Caribbean is controlled by both the strength of the meridional overturning in the North Atlantic and by changes in the tropical wind field, controlling the position of the Intertropical Convergence Zone (ITCZ). The Caribbean inflow through the southernmost Lesser Antilles Passages is considered to balance the return flow for the modern export of NADW, while nearly all of the wind driven inflow occurs north of Martinique (ca. $\left.15^{\circ} \mathrm{N}\right)$.
[6] The modern Caribbean throughflow shows strong wind-driven seasonality with maximum values in spring and summer, and minimum values in fall [Schott et al., 1988; Molinari et al., 1990; Larsen, 1992; Johns et al., 2002]. From spring to summer, when the ITCZ moves northward, the inflow to the southern Caribbean appears to result from a strengthened Guyana Current, which enters through the southernmost Lesser Antilles Passages [MüllerKarger et al., 1989]. This inflow is considered to contribute to lower SSS in the eastern Caribbean because of the admixture of waters from the Amazon and Orinoco rivers which reach their maximum discharge in June and August, respectively.

[7] In August, when the ITCZ reaches its northernmost position at $6-10^{\circ} \mathrm{N}$ [Philander and Pacanowski, 1986], the development of a cyclonic circulation cell southeast of the Lesser Antilles blocks the direct inflow of South Atlantic water into the Caribbean via the Guyana Current [MüllerKarger et al., 1989; Johns et al., 2002]. Until January, the northward transport along the coast of South America is retroflected to the east and provides the western source of the North Equatorial Countercurrent (NECC). In spite of the retroflection, a significant amount of Amazon freshwater is carried northwestward and can be traced into the central Caribbean Sea to $\sim 70^{\circ} \mathrm{W}$ [Hellweger and Gordon, 2002], however, with a lag time of approximately 6 months. The largest river draining directly into the western Caribbean is the Magdalena River with an average discharge of $6.9 * 10^{3} \mathrm{~m}^{3} \mathrm{~s}^{-1}$, which is 2 orders of magnitude lower than the average Amazon discharge of $1.6 * 10^{5} \mathrm{~m}^{3} \mathrm{~s}^{-1}$ (River Discharge Database, Center for Sustainability and Global Environment, Gaylord Nelson Institute for Environmental Studies, University of Wisconsin-Madison, 2003, available at http://www.sage.wisc.edu/riverdata/).

[8] In addition to freshwater supply from the Amazon and Orinoco rivers, Caribbean SSS is controlled by seasonal changes in the evaporation/precipitation ratio. The migration of the ITCZ leads to a dry (February-May) and a wet season (August-October) north of $\sim 5^{\circ} \mathrm{N}$ [Müller-Karger et al., 1989]. In the western Caribbean, these phases are roughly parallel to changes in SSS. According to Dessier and Donguy [1994], and Hellweger and Gordon [2002], modern evaporation/precipitation west of $70^{\circ} \mathrm{W}$ exerts a stronger control on SSS than the freshwater supply from the Amazon.

[9] At $80 \mathrm{~m}$ water depth (the assumed main habitat depth of G. sacculifer), modern differences in SST and SSS between sites $999\left(25.5^{\circ} \mathrm{C}, 36.5\right.$ salinity units $)$ and 1000 $\left(26.5^{\circ} \mathrm{C}, 36.1\right.$ salinity units) [Levitus and Boyer, 1994; Levitus et al., 1994] are small. At 400-500 m water depth (assumed main habitat depth of G. crassaformis), temperature and salinity differ slightly between sites $999\left(11^{\circ} \mathrm{C}\right.$, 35.4 salinity units) and $1000\left(14^{\circ} \mathrm{C}, 35.6\right.$ salinity units) [Levitus and Boyer, 1994; Levitus et al., 1994].

\section{Material and Methods}

\subsection{Compilation of Proxy Data}

[10] Caribbean ODP site 1000 is located in the Pedro Channel between Nicaragua and Jamaica $\left(16^{\circ} 33^{\prime} \mathrm{N}\right.$, 

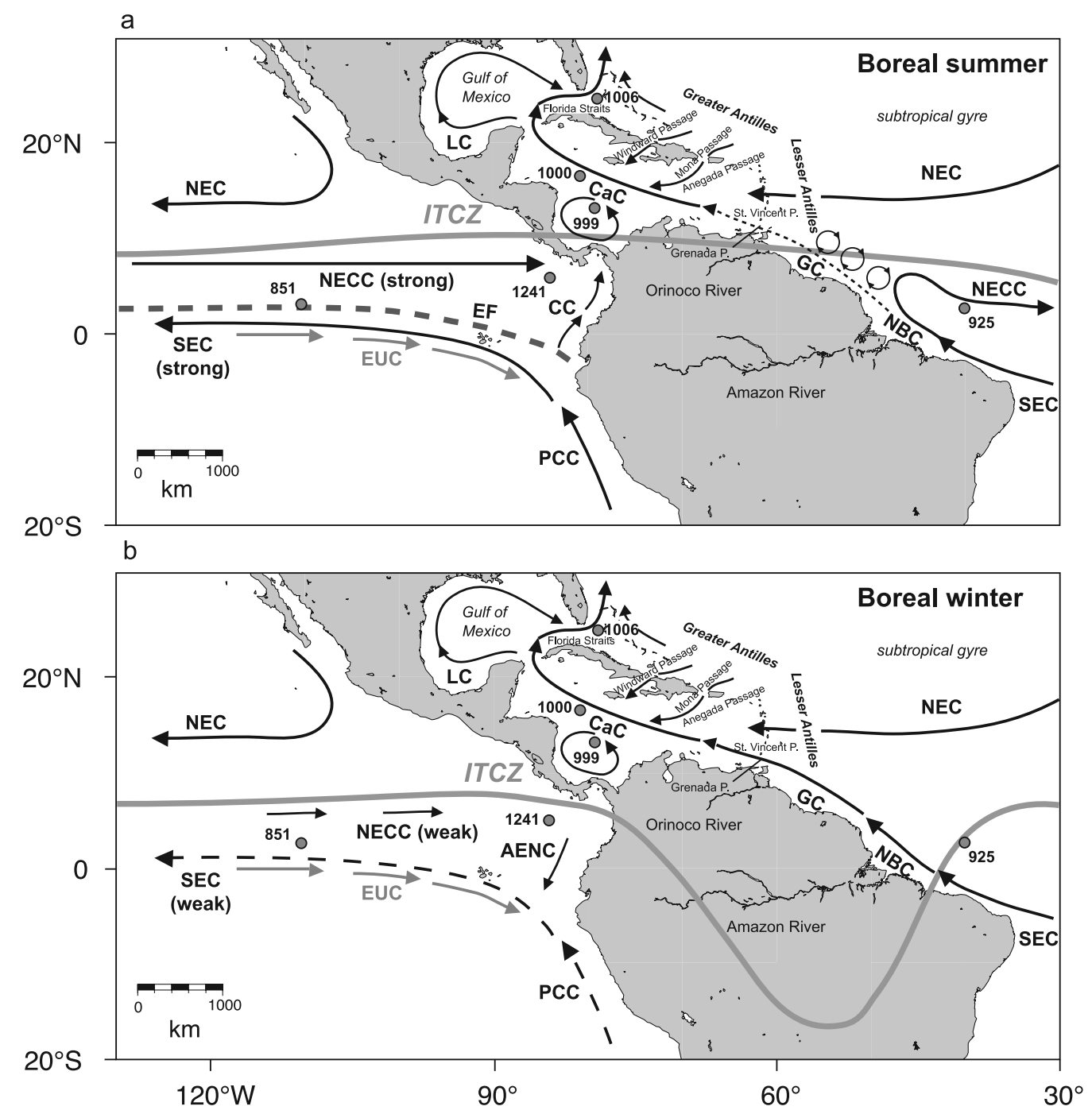

Figure 1. Modern oceanographic setting of the tropical western Atlantic and eastern Pacific showing major surface current systems. The locations of ODP sites discussed in this study are indicated. (a) Scenario during boreal summer with the ITCZ at its northernmost position. The Atlantic SEC is retroflected toward the east. (b) Scenario during boreal winter with the ITCZ at its southern position. The Atlantic GC enters the Caribbean via the Lesser Antilles Passages. Abbreviations are NEC, North Equatorial Current; NECC, North Equatorial Counter Current; SEC, South Equatorial Current; NBC, North Brazil Coastal Current; GC, Guyana Current; CaC, Caribbean Current; LC, Loop Current; PCC, Peru-Chile Current; CC, Colombia Current; EUC, Equatorial Undercurrent; AENC, Annual El Niño Current; EF, Equatorial Front; and ITCZ, Intertropical Convergence Zone.

$\left.79^{\circ} 52^{\prime} \mathrm{W}\right)$ at a water depth of $916 \mathrm{~m}$ [Sigurdsson et al., 1997]. Carbonate preservation is excellent according to the shallow site location far above the lysocline. The interval from 5.6 to $2.4 \mathrm{Ma}$ was sampled every $10 \mathrm{~cm}$, corresponding to a time resolution better than $3 \mathrm{kyr}$. A nearly complete late Miocene-Pliocene interval was cored at hole 1000A. We also sampled cores $1 \mathrm{R}$ and $2 \mathrm{R}$ from hole $\mathrm{B}$ to stratigraphically splice across the drilling-disturbed intervals of cores $1000 \mathrm{~A}-10 \mathrm{H}$ and $1000 \mathrm{~A}-13 \mathrm{H}$, respectively.

[11] For isotope analyses of the mixed layer dwelling foraminifera $G$. sacculifer (without sac-like final chamber) and the deep dwelling foraminifera G. crassaformis, 10 specimens were picked from the $315-400 \mu \mathrm{m}$ size fraction. For the benthic $\delta^{18} \mathrm{O}$ record, one to three tests of the epibenthic species Cibicidoides wuellerstorfi ( $>400 \mu \mathrm{m}$ size fraction) were analyzed. Prior to analysis, specimens were slightly crushed and ultrasonically cleaned with methanol. The excess liquid and mud were siphoned off and the samples were dried at $60^{\circ} \mathrm{C}$.

[12] Isotope analyses were run at IFM-GEOMAR (Kiel) on a Finnigan MAT 252 Mass Spectrometer with an automated Kiel carbonate preparation device. Analytical 
precision was better than $0.07 \%$ for $\delta^{18} \mathrm{O}$ and $0.04 \%$ for $\delta^{13} \mathrm{C}$. The values are reported relative to Peedee belemnite (PDB), based on calibrations directly to National Bureau of Standards (NBS) 19. The $\delta^{18} \mathrm{O}$ values of $C$. wuellerstorfi are adjusted to seawater equilibrium by $+0.64 \%$ [Shackleton and Hall, 1984].

[13] For $\mathrm{Mg} / \mathrm{Ca}$ analyses, 20 well-preserved specimens of G. sacculifer $(\sim 0.5-1.2 \mathrm{mg})$ were selected from the $315-$ $400 \mu \mathrm{m}$ size fraction. They were gently crushed between glass plates in order to open all chambers and were subsequently cleaned according to Barker et al. [2003]. This includes several rinses with distilled deionized water and methanol (suprapur) and in-between ultrasonic treatment, two times 10 min soaking of the samples in a hot $\left(97^{\circ} \mathrm{C}\right)$ oxidizing $1 \% \mathrm{NaOH} / \mathrm{H}_{2} \mathrm{O}_{2}$ solution $(10 \mathrm{~mL} 0.1 \mathrm{~N}$

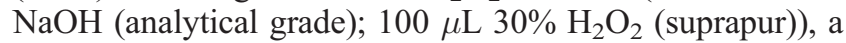
weak acid leach $\left(0.001 \mathrm{M} \mathrm{QD} \mathrm{HNO}_{3}\right)$ and finally dissolution in QD $0.075 \mathrm{M} \mathrm{HNO}_{3}$. Analyses were performed on an ICP-AES (ISA Jobin Yovin-Spex Instruments S.A. GmbH) at IFM-GEOMAR (Kiel).

[14] We used the software package AnalySeries 1.2 from Paillard et al. [1996] for time series analyses and stratigraphic correlation in order to establish an age model for Site 1000 .

\subsection{Design of Numerical Experiments}

[15] Numerical experiments were performed with an adjusted version of the 'paleo release' of the NCAR (National Center of Atmospheric Research) Community Climate System Model CCSM2.0.1. The global climate model is composed of four separate components representing atmosphere, ocean, land, and sea ice. The resolution of the atmospheric component is given by $\mathrm{T} 31\left(3.75^{\circ}\right.$ by $3.75^{\circ}$ transform grid) spectral truncation for 26 layers, while the ocean has a mean resolution of $3.6^{\circ}$ by $1.6^{\circ}$ with 25 levels. The latitudinal resolution of the oceanic model grid is variable, with finer resolution near the equator $\left(\sim 0.9^{\circ}\right)$. The model has been used previously for other paleoclimatic applications [e.g., Yoshimori et al., 2005].

[16] The present-day control run of the original 'paleo release' reveals some unacceptable shortcomings of the model. In particular, the thermohaline circulation of the Atlantic Ocean spins down such that the volume export of NADW to the Southern Ocean drops below $2 \mathrm{~Sv}$ (1 $\mathrm{Sv}=$ $10^{6} \mathrm{~m}^{3} / \mathrm{s}$ ). By applying some modifications to the original model setup, we were able to substantially improve the model performance. These adjustments include a regional freshwater flux correction for the Arctic realm and slight deepening of the Greenland-Scotland ridge. The 'paleo release' of CCSM2.0.1, including these adjustments, is referred to as $\mathrm{CCSM} 2 / \mathrm{T} 31 \times 3 \mathrm{a}$ to reflect the atmospheric resolution ('T31'), the average resolution of the ocean grid (' $\mathrm{x} 3$ ') as well as the implementation of adjustments ('a'). Owing to the regional limitation of the surface freshwater flux correction, CCSM2/T31x3a behaves like a non-fluxcorrected model with respect to tropical-subtropical climate dynamics [Prange, 2006].

[17] In order to achieve statistical equilibria, we applied a deep ocean acceleration technique. This approach allows for increasing tracer time steps with depth, exploiting the relaxation of the Courant-Friedrichs-Lewy constraint because of diminishing current speeds in the deep ocean. Such an asynchronous integration technique has proven useful for searching equilibrium solutions without any interest in the transient behavior of the model [Bryan and Lewis, 1979; Bryan, 1988]. This approach, however, does not ensure tracer conservation [Danabasoglu et al., 1996]. Danabasoglu [2004] has recently shown that equilibrium abyssal temperature and salinity errors, induced by the deep ocean acceleration technique, measure $\sim 0.1^{\circ} \mathrm{C}$ and 0.1 salinity units in an ocean model subject to realistic forcing. These deep ocean hydrographic errors are acceptable for our application. Using the same oceanic model grid as Danabasoglu [2004], we applied a similar deep ocean acceleration scheme below $1300 \mathrm{~m}$, with an acceleration factor of 50 below $2500 \mathrm{~m}$.

[18] We performed two equilibrium integrations: one experiment with closed CAS (present-day control run), and one experiment with open CAS (with all other boundary conditions identical to the control run). In the latter experiment, the CAS has a depth of $800 \mathrm{~m}$ and a width of two tracer grid points $(\sim 200 \mathrm{~km})$. In both experiments, we adopted the atmospheric composition of $1990 \mathrm{AD}$ and initialized the model with modern observational data sets. After 300-year depth-accelerated spinups, the model runs were extended by centennial synchronous integration phases. This gives a total integration time of 400 surface years for each experiment, corresponding to $\sim 15,000$ deep ocean years. The synchronous extensions are of utmost importance to correctly capture oceanic variability [Danabasoglu et al., 1996; Wang, 2001; Danabasoglu, 2004], and to test the stability of the accelerated equilibrium solutions [cf. Peltier and Solheim, 2004]. In the present study, only the last 90 years of the synchronous integration phases shall serve for a statistical evaluation of the modeled climates.

[19] Both model experiments yielded stable climatic equilibria that will be discussed extensively and on a global scale in a forthcoming paper. For the present study, the model's capability to simulate the hydrography of the Caribbean and its surroundings is of particular importance. In the present-day control run, we find that the overall Caribbean salinity distribution is captured rather well by CCSM2/T31x3a (Figure 2a). In the upper ocean, the main shortcoming is an Atlantic water inflow between Hispaniola and the South American continent, which has a fresh bias of 0.4 salinity units. Moreover, salinities in the Gulf of Mexico, along the Florida Current, as well as in the tropical eastern Pacific are $0.2-0.4$ salinity units too high. The situation with an open CAS is discussed in section 7.1.

\section{Estimation of the Calcification Depth of $G$. sacculifer and G. crassaformis}

[20] In order to reconstruct changes in upper ocean water signatures as derived from planktonic $\delta^{18} \mathrm{O}$ data, the habitat depth of planktonic foraminifers is of basic interest. We thus tried to assess the calcification depth of G. sacculifer and G. crassaformis in the Caribbean. The present knowledge of their habitat is mainly based on tow studies. For $G$. sacculifer, most studies consistently suggest a main 

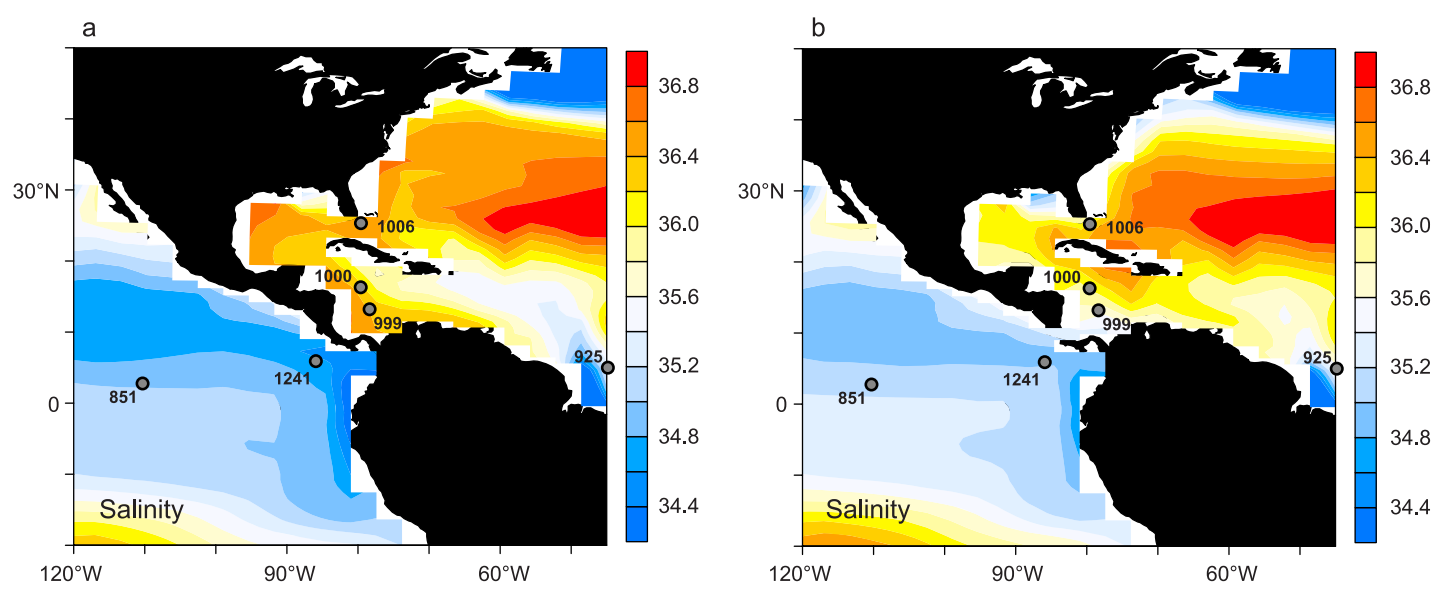

Figure 2. Annual mean salinity distribution as simulated by CCSM2/T31x3a averaged over the top 110 m. (a) Present-day control run. (b) Experiment with open CAS. Positions of ODP sites discussed in this study are indicated.

abundance depth in the range of 0-80 $\mathrm{m}$ [Fairbanks et al., 1982; Hemleben and Spindler, 1983; Ottens, 1992; Kemle-von-Mücke and Oberhänsli, 1999; Schmuker and Schiebel, 2002], although living specimens are also found in water depths of up to $1000 \mathrm{~m}$ [e.g., Kemle-von-Mücke and Oberhänsli, 1999]. It is well known that G. sacculifer adds calcite in deeper and cooler water masses during gametogenesis, thereby accumulating ${ }^{18} \mathrm{O}$ [e.g., Duplessy et al., 1981; Lohmann, 1995]. Hence it has to be considered that the $\delta^{18} \mathrm{O}_{\text {sac }}$ signal represents a mixture of shell parts that calcified at shallow and deeper water depths. We measured G. sacculifer without sac-like formed last chamber to reduce isotopic signals from gametogenetic calcification [Duplessy et al., 1981]. The subthermocline dweller $G$. crassaformis belongs to the species with the deepest known calcification depth $(250-500 \mathrm{~m})$ [Niebler et al., 1999]. Accordingly, the $\delta^{18} \mathrm{O}$ values of $G$. crassaformis $\left(\delta^{18} \mathrm{O}_{\text {cras }}\right)$ should be higher than those of $G$. sacculifer as temperature decreases with increasing water depth.

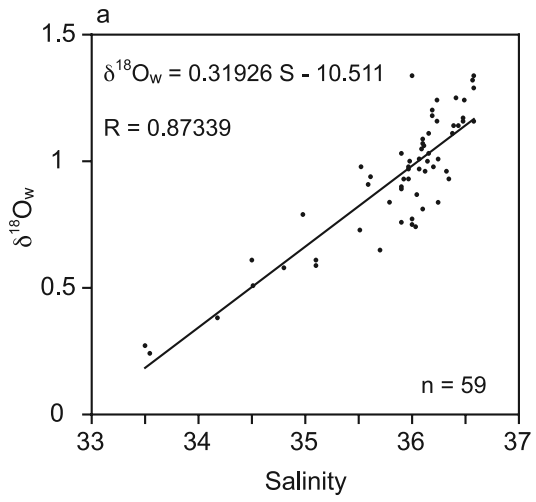

[21] We measured stable isotopes from 14 Caribbean core top samples collected during $R V$ Sonne Cruise SO 164 [Nürnberg et al., 2002] to compare the expected habitat depths of $G$. sacculifer $(0-80 \mathrm{~m})$ and $G$. crassaformis $(250-500 \mathrm{~m})$ with habitat depths as suggested from the $\delta^{18} \mathrm{O}$ foraminiferal value. The $\delta^{18} \mathrm{O}$-derived habitat depth is provided by comparisons of measured $\delta^{18} \mathrm{O}$ and calculated equilibrium calcite $\delta^{18} \mathrm{O}\left(\delta^{18} \mathrm{O}_{\mathrm{C}}\right.$ as a function of habitat temperature and $\delta^{18} \mathrm{O}$ seawater $\left.\left(\delta^{18} \mathrm{O}_{\mathrm{W}}\right)\right)$. The $\delta^{18} \mathrm{O}_{\mathrm{C}}$ for G. sacculifer was calculated from $\delta^{18} \mathrm{O}_{\mathrm{W}}$ and temperature (T) by applying the paleotemperature equation from Spero et al. [2003]:

$$
\delta^{18} \mathrm{O}_{\mathrm{C}}=\left[\mathrm{T}-12.0-5.67\left(\delta^{18} \mathrm{O}_{\mathrm{W}}-0.27\right)\right] /(-5.67)
$$

[22] We chose the equation of Spero et al. [2003], because the factors derived from laboratory data are G. sacculifer-

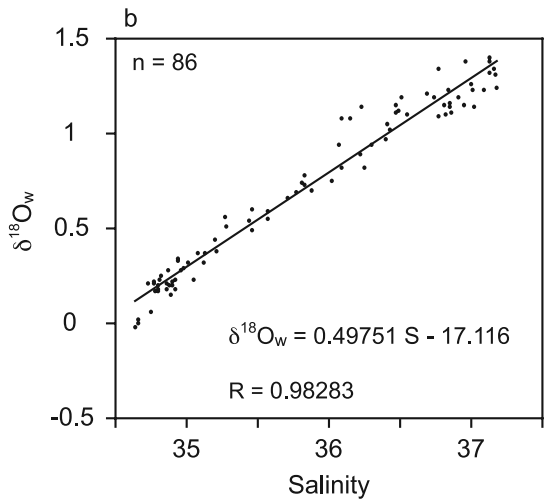

Figure 3. (a) Modern $\delta^{18} \mathrm{O}$ seawater $\left(\delta^{18} \mathrm{O}_{\mathrm{w}}\right)$-salinity relationship for the southern Caribbean, $0-100 \mathrm{~m}$ water depth. (b) Modern $\delta^{18} \mathrm{O}_{\mathrm{w}}$-salinity relationship for the southern Caribbean, $100-1000 \mathrm{~m}$ water depth. The $\delta^{18} \mathrm{O}_{\mathrm{w}}$ and salinity data are from Schmidt et al. (Global Seawater Oxygen-18 Database, 1999). 
Table 1. Calculated Habitat Depth for G. sacculifer and G. crassaformis From Caribbean Core Top Samples Collected During R/V Sonne Cruise 164 (May 22 to June 28, 2002) ${ }^{\mathrm{a}}$

\begin{tabular}{|c|c|c|c|c|c|c|}
\hline Station & Latitude & Longitude & $\begin{array}{c}\delta^{18} \mathrm{O}_{s a c} \\
\text { Measured, } \\
\% \text { \% } \\
\end{array}$ & $\begin{array}{c}\text { Estimated } \\
\text { Habitat Depth } \\
\text { G. sacculifer, } \mathrm{m} \\
\end{array}$ & $\begin{array}{c}\delta^{18} \mathrm{O}_{\text {cras }} \text { Measured, } \\
\% 0\end{array}$ & $\begin{array}{c}\text { Estimated Habitat } \\
\text { Depth G. crassaformis, } \mathrm{m}\end{array}$ \\
\hline SO16401-3 & $13^{\circ} 50.195 \mathrm{~N}$ & $74^{\circ} 09.028 \mathrm{~W}$ & -1.354 & 92 & 1.815 & 440 \\
\hline SO16402-3 & $15^{\circ} 18.290 \mathrm{~N}$ & $72^{\circ} 47.060 \mathrm{~W}$ & -1.386 & 119 & 1.791 & 497 \\
\hline SO16403-3 & $16^{\circ} 32.400 \mathrm{~N}$ & $72^{\circ} 12.310 \mathrm{~W}$ & -1.577 & 113 & 1.513 & 452 \\
\hline SO16404-2 & $17^{\circ} 16.380 \mathrm{~N}$ & $71^{\circ} 39.090 \mathrm{~W}$ & -1.633 & 99 & 1.223 & 404 \\
\hline SO16407-3 & $21^{\circ} 19.460 \mathrm{~N}$ & $74^{\circ} 08.760 \mathrm{~W}$ & -1.526 & 76 & - & - \\
\hline SO16419-3 & $21^{\circ} 14.710 \mathrm{~N}$ & $74^{\circ} 20.990 \mathrm{~W}$ & -1.375 & 94 & - & - \\
\hline SO16420-2 & $16^{\circ} 45.490 \mathrm{~N}$ & $71^{\circ} 29.220 \mathrm{~W}$ & -1.366 & 131 & 1.657 & 484 \\
\hline SO16421-3 & $16^{\circ} 06.000 \mathrm{~N}$ & $70^{\circ} 30.000 \mathrm{~W}$ & -1.416 & 108 & 1.586 & 436 \\
\hline SO16422-2 & $15^{\circ} 40.000 \mathrm{~N}$ & $68^{\circ} 20.000 \mathrm{~W}$ & -1.255 & 116 & 1.694 & 458 \\
\hline SO16423-3 & $15^{\circ} 34.010 \mathrm{~N}$ & $65^{\circ} 08.090 \mathrm{~W}$ & -1.254 & 112 & 1.813 & 474 \\
\hline SO16424-3 & $14^{\circ} 11.890 \mathrm{~N}$ & $63^{\circ} 25.430 \mathrm{~W}$ & -1.497 & 83 & 1.894 & 458 \\
\hline SO16425-3 & $14^{\circ} 41.250 \mathrm{~N}$ & $59^{\circ} 44.480 \mathrm{~W}$ & -1.483 & 88 & 2.189 & 548 \\
\hline SO16448-2 & $15^{\circ} 57.020 \mathrm{~N}$ & $60^{\circ} 55.000 \mathrm{~W}$ & -1.740 & 68 & 1.718 & 437 \\
\hline SO16450-3 & $15^{\circ} 21.250 \mathrm{~N}$ & $59^{\circ} 16.940 \mathrm{~W}$ & -1.221 & 113 & 2.028 & 526 \\
\hline Mean & & & & $100 \pm 18$ & & $468 \pm 41$ \\
\hline
\end{tabular}

${ }^{a}$ Estimated habitat depth $(\mathrm{m})$ reflects the water depth where the calculated equilibrium calcite $\delta^{18} \mathrm{O}$ value equals the measured $\delta^{18} \mathrm{O}$ value.

specific. To determine $\delta^{18} \mathrm{O}_{\mathrm{W}}$, we established a $\delta^{18} \mathrm{O}_{\mathrm{W}^{-}}$ salinity relationship for the Caribbean $(0-100 \mathrm{~m}$ water depth, Figure 3a) using $\delta^{18} \mathrm{O}_{\mathrm{W}}$ and salinity (S) data from G. A. Schmidt et al. (Global Seawater Oxygen-18 Database, 1999, available at http://www.giss.nasa.gov/data/o18data/, hereinafter referred to as Schmidt et al., Global Seawater Oxygen-18 Database, 1999):

$$
\delta^{18} \mathrm{O}_{\mathrm{W}}\left(\text { Caribbean }_{0-100 \mathrm{~m}}\right)=0.319 \mathrm{~S}-10.511
$$

[23] Then, we calculated $\delta^{18} \mathrm{O}_{\mathrm{W}}$ and $\delta^{18} \mathrm{O}_{\mathrm{C}}$ profiles $(0-$ $200 \mathrm{~m}$ water depth) for each core top station, using annual mean $\mathrm{T}$ and $\mathrm{S}$ data from the corresponding $1^{\circ}$ grid box of the World Ocean Atlas 2001 [Conkright et al., 2002]. The $\delta^{18} \mathrm{O}_{\mathrm{W}}$ values were scaled to PDB by subtracting $0.27 \%$ as indicated in equation (1) [Hut, 1987]. The comparison between measured $\delta^{18} \mathrm{O}_{\text {sac }}$ and calculated $\delta^{18} \mathrm{O}_{\mathrm{C}}$ suggests an average habitat depth of $100 \mathrm{~m} \pm 18 \mathrm{~m}$ (Table 1). We are aware that the estimates for each station represent a mean of different calcifying depths, although $G$. sacculifer may have lived predominantly within the upper $80 \mathrm{~m}$ of the water column. Hence it has to be considered for paleoceanographic interpretations that the $\delta^{18} \mathrm{O}_{\text {sac }}$ signal is not a pure upper mixed layer signal, although the application of other paleotemperature equations would provide significantly shallower calcification depths $(\sim 30-75 \mathrm{~m})$ [e.g., O’Neil et al., 1969; Shackleton, 1974] (for discussion see Mulitza et al. [2004]).

[24] For the deep dwelling foraminifera G. crassaformis, unfortunately, no species-specific paleotemperature equation exists. Therefore we used the paleotemperature equation from Shackleton [1974] to calculate equilibrium $\delta^{18} \mathrm{O}_{\mathrm{C}}$ :

$$
\begin{aligned}
\delta^{18} \mathrm{O}_{\mathrm{C}}= & \left(\delta^{18} \mathrm{O}_{\mathrm{W}}-0.27\right)+4.38 /(2 \times 0.1) \\
& -\left(4.38^{2} /\left(4 \times 0.1^{2}\right)-(16.9-\mathrm{T}) / 0.1\right)^{0.5}
\end{aligned}
$$

[25] To estimate $\delta^{18} \mathrm{O}_{\mathrm{W}}$, we used the modern ocean $\delta^{18} \mathrm{O}$ salinity relationship of Broecker [1989], which is similar to the Caribbean $\delta^{18} \mathrm{O}$-salinity relationship for water depths ranging from 100 to $1000 \mathrm{~m}$ (Figure 3b):

$$
\delta^{18} \mathrm{O}_{\mathrm{W}}=0.5 \mathrm{~S}-17
$$

[26] The $\delta^{18} \mathrm{O}_{\mathrm{C}}$ was calculated for different water depths $(200-700 \mathrm{~m})$ and compared with measured core top G. crassaformis $\delta^{18} \mathrm{O}$ values in order to estimate the isotope-derived calcification depth. The match between measured $\delta^{18} \mathrm{O}_{\text {cras }}$ and calculated $\delta^{18} \mathrm{O}_{\mathrm{C}}$ suggests a calcification depth of $468 \pm 41 \mathrm{~m}$ (Table 1$)$.

\section{Age Model}

[27] The age model of site 1000 is mainly based on benthic (C. wuellerstorfi) isotope stratigraphy and biostratigraphy. The opportunity for an astronomical calibration of the Late Miocene to Pliocene timescale was limited as no composite depth exists, which would cover and identify coring gaps usually occurring at core breaks. The timescale was achieved by identifying eye-catching benthic oxygen isotope stages according to the Miocene-Pliocene isotope nomenclature of Shackleton et al. [1995]. We then correlated the oxygen isotope events to the isotope standard timescale from site $925 / 926$, which was orbitally tuned to the astronomical solution of Laskar et al. [1993] [Bickert et al., 1997; Tiedemann and Franz, 1997; Shackleton and Hall, 1997]. In addition, we used the benthic $\delta^{18} \mathrm{O}$ record from site 1241 as reference (Figure 4), since its orbitally tuned isotope stratigraphy is in agreement with the record from site 925/ 926 [Tiedemann et al., 2006]. This procedure resulted in an initial age model for site 1000 and displays the general dominance of 41-kyr climate fluctuations (Figure 4). The age model suggests that core breaks are associated with stratigraphic gaps of up to $70 \mathrm{kyr}$. The relatively large gap between 3.66 Ma and 3.8 Ma represents drilling-disturbed 


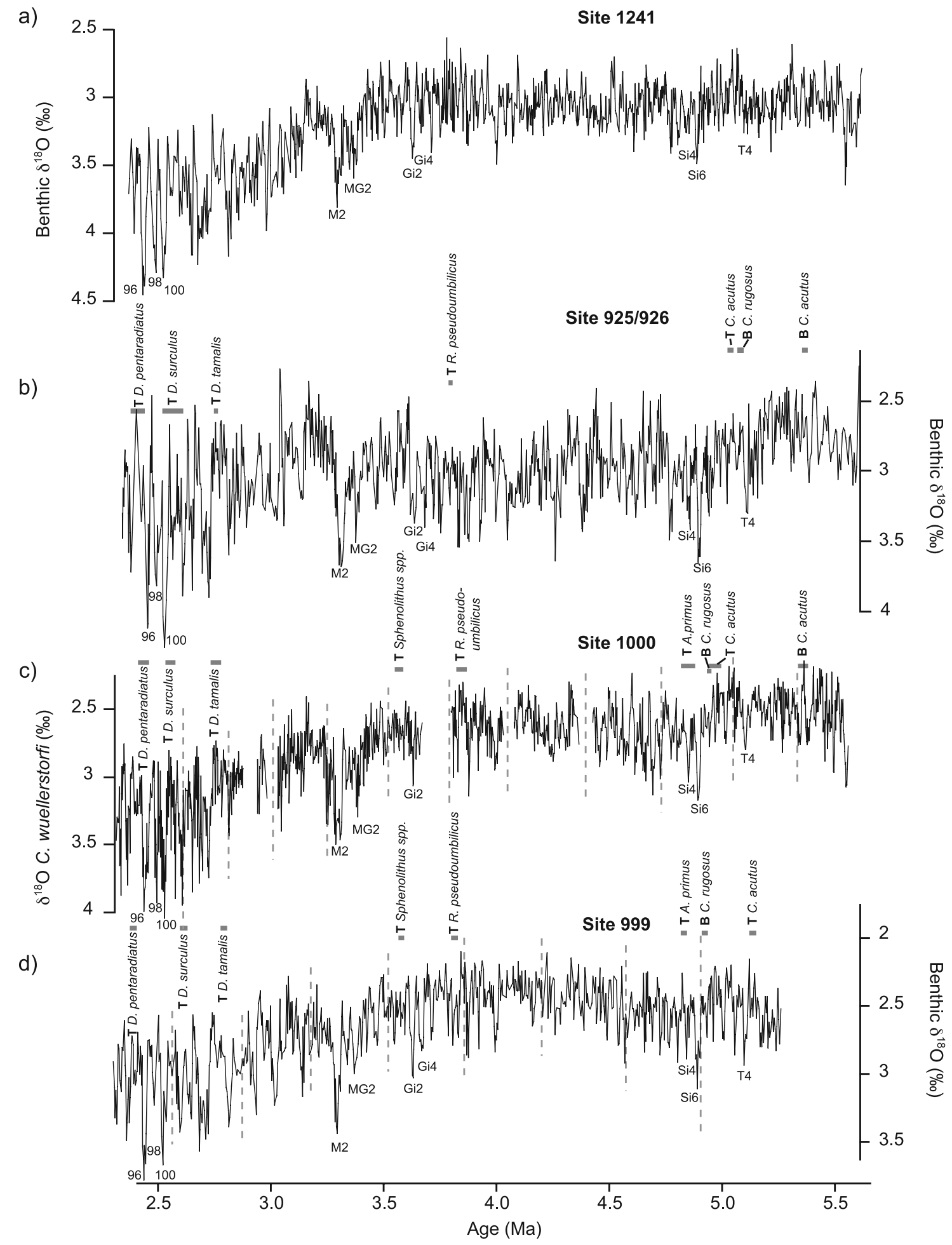

Figure 4. Orbitally tuned benthic $\delta^{18} \mathrm{O}$ reference records of (a) tropical east Pacific site 1241 [Tiedemann et al., 2006] and (b) western Atlantic sites 925/926 [Bickert et al., 1997; Tiedemann and Franz, 1997; Shackleton and Hall, 1997] correlated to benthic $\delta^{18} \mathrm{O}$ records from Caribbean sites (c) 1000 (this study) and (d) 999 [Haug and Tiedemann, 1998]. Pronounced isotope stages and biostratigraphic events are indicated. Dashed lines indicate core breaks at Caribbean sites. 


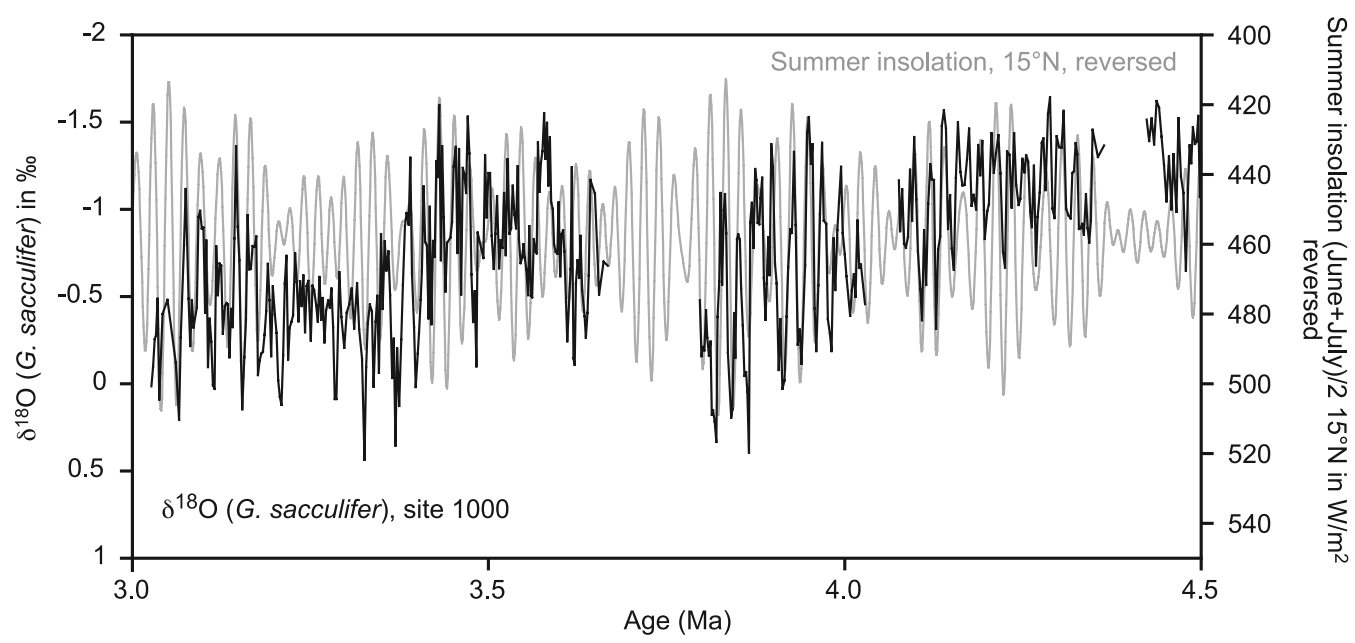

Figure 5. Comparison of the planktonic $\delta^{18} \mathrm{O}$ record (G. sacculifer) from Caribbean site 1000 to Northern Hemisphere (NH) summer insolation (June plus July $/ 2 ; 15^{\circ} \mathrm{N}$; reversed) [Laskar et al., 1993]. In general, high $\delta^{18} \mathrm{O}$ values (interpreted as high SSS) are linked to $\mathrm{NH}$ summer insolation maxima.

intervals of overlapping cores 1000A-13H and 1000B-2R (sections 6-7) that were not sampled.

[28] Our age model reveals dominant planktonic $\delta^{18} \mathrm{O}$ cycles at precessional periodicities (23 and $19 \mathrm{kyr})$ for the time interval from 3 to $4.4 \mathrm{Ma}$ (cores 11, 12, 14, 15), whereas maxima in planktonic $\delta^{18} \mathrm{O}$ match precessional maxima in Northern Hemisphere $(\mathrm{NH})$ summer insolation (Figure 5). We used this information to further verify the age model. Spectral analyses in the depth domain suggest that the response to precession corresponds to cycles ranging from $100-110 \mathrm{~cm}$ (cores $11-14$ ) to $80 \mathrm{~cm}$ (core 15). The counting of these cycles yielded the time span for each core. Accordingly, the appropriate time span for each core should be in agreement with the initial age model. In case of disagreements, we reassigned our correlation between the benthic isotope records but we did not adjust the planktonic $\delta^{18} \mathrm{O}$ signal to variations in orbital precession. This procedure improved the initial age model and helped to identify stratigraphic gaps associated with core breaks (Figures 4 and 5). Furthermore, the remarkable similarity between benthic $\delta^{13} \mathrm{C}$ records from sites 1000 (R. Tiedemann et al., manuscript in preparation, 2006), 925/926, and 1241 corroborated the robustness of the age model.

[29] The nannofossil age assignments obtained from our final age model correspond within their error range to those calculated by Raffi and Flores [1995], and Shackleton et al. [1995], except for the nannofossil events of top (T.) C. acutus, base (B.) C. rugosus, and T. D. quinqueramus around the Miocene/Pliocene boundary [Backman and Raffi, 1997] (Figure 4). According to Backman and Raffi [1997] B. C. rugosus was estimated to occur approximately one obliquity cycle before T. C. acutus. In contrast, Kameo and Bralower [2000] suggest that at site 1000, T. C. acutus appears at greater sediment depths than B. C. rugosus, leaving behind a stratigraphic problem that cannot be resolved within this study. At site 1000, both events occur within core 17 and $\sim 100$ kyr later than suggested by Backman and Raffi [1997]. The stratigraphic adjustment of core 17 is based on simple identification of pronounced marine isotope stages (MIS) Si4 and Si6 (Figure 4), whereas the two events occur not more than two obliquity cycles later and therefore suggest a younger age. The age assignment of B. C. acutus is almost identical to the age calculated by Backman and Raffi [1997].

[30] For direct comparisons with isotope records from site 999, we adjusted the benthic oxygen isotope record from site 999 [Haug and Tiedemann, 1998] to reference sites $925 / 926$ and 1241. The alignment of most nannofossil events between sites 1000 and 999 correlates within an error range of less than half an obliquity cycle. Although MIS 96-100 are clearly recognized at both sites, the associated stratigraphic position of T. D. surculus and T. D. pentaradiatus deviates by up to two obliquity cycles. However, the estimated ages for T. D. surculus, and T. $D$. pentaradiatus at sites 999 and 1000 are within the estimated time span for these events given by Raffi and Flores [1995]. A larger biostratigraphic uncertainty results from the position of T. C. acutus at site 999. At site 1000, T. C. acutus overlaps with B. C. rugosus, whereas at site 999 both events are separated by $\sim 170$ kyr. This uncertainty cannot be ascribed to a coring gap, since both events are present within one core at each site. In addition to the lithostratigraphy [Sigurdsson et al., 1997], the presence of 41-kyr isotope cycles in the benthic record as well as the clear identification of MIS T4 provide no indication for a sediment slump at site 999, which could explain the time offset. The supply of reworked older sediment material would have resulted in an opposite effect by moving T. $C$. acutus upcore. Hence the stratigraphic position of T. $C$. acutus remains problematic.

[31] We did not modify the age model of site 851 [Cannariato and Ravelo, 1997] because the $\delta^{18} \mathrm{O}_{\text {sac }}$ record 


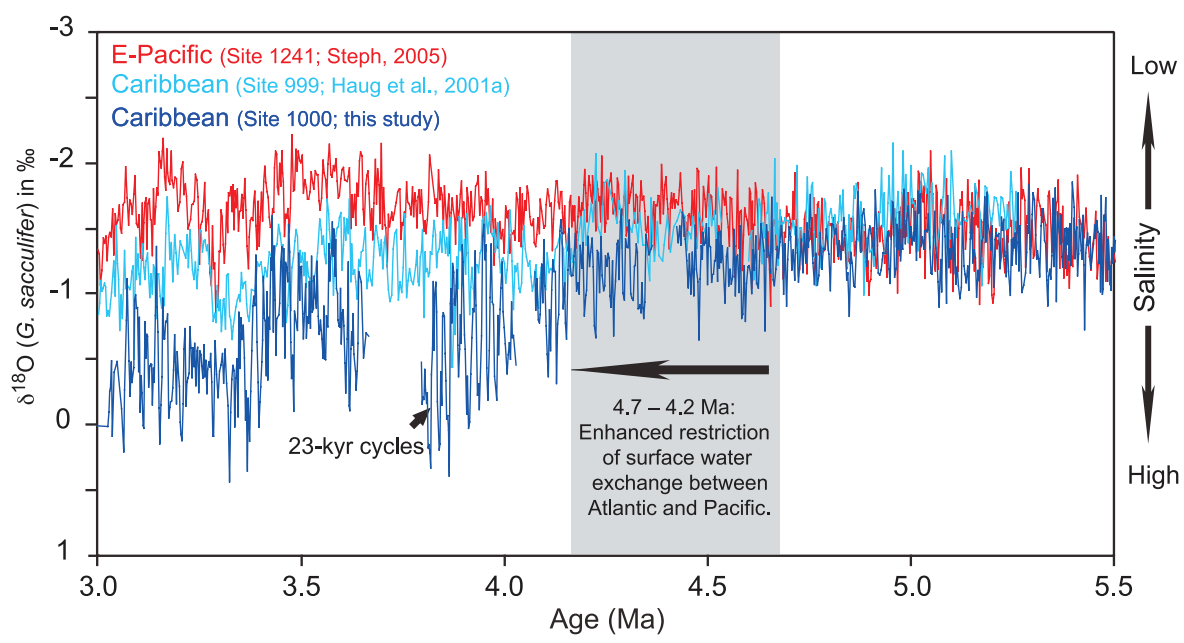

Figure 6. Comparison of planktonic $\delta^{18} \mathrm{O}$ records (G. sacculifer) from Caribbean sites 1000 (dark blue, this study) and 999 (light blue) [Haug et al., 2001a] to the $\delta^{18} \mathrm{O}_{\text {sac }}$ record from tropical east Pacific site 1241 (red) [Steph, 2005; Steph et al., 2006]. The time interval from 4.7 Ma to 4.2 Ma is marked by an overall increase in Caribbean SSS with strong local differences in Caribbean SSS (between sites 999 and 1000 ) after 4.2 Ma. The development of pronounced 23-kyr cycles in planktonic $\delta^{18} \mathrm{O}_{\text {sac }}$ at site 1000 started at $\sim 4.4-4.2$ Ma.

from site 851 provided an excellent match with that from reference site 1241 (see section 6).

\section{Evolution of Pliocene SSS in the Caribbean}

[32] The new planktonic $\delta^{18} \mathrm{O}_{\text {sac }}$ record from site 1000 (Figure 6) adds valuable information to the results of Haug et al. [2001a]. Their study was based on a comparison of $\delta^{18} \mathrm{O}_{\text {sac }}$ records from Caribbean site 999 and Pacific site 851 . The divergence between both records since $4.7 \mathrm{Ma}$ and the $0.5 \% \delta^{18} \mathrm{O}$ increase at site 999 after 4.2 Ma were interpreted to reflect an increase of 1 salinity unit in Caribbean SSS in response to the shoaling of the CAS. Our comparison of $\delta^{18} \mathrm{O}_{s a c}$ records from Caribbean site 999 and Pacific site 1241 led to the same result, because absolute values and fluctuations at Pacific sites 851 and
1241 are almost identical (Figure 7), although site 1241 is located $3^{\circ}$ further north and $24^{\circ}$ further east than site 851 and thus closer to the CAS [Steph, 2005; Steph et al., 2006].

[33] Caribbean site 1000 reveals distinctly higher shortterm isotope fluctuations with generally higher $\delta^{18} \mathrm{O}_{s a c}$ values in comparison to the more southern site 999. The $\delta^{18} \mathrm{O}_{s a c}$ values vary from -1.8 to $0.5 \%$ compared to -2.1 to $-0.5 \%$ at site 999 . During the late Miocene and early Pliocene (5.6-4.4 Ma), $\delta^{18} \mathrm{O}_{s a c}$ values were $\sim 0.2 \%$ higher at site 1000 (Figure 6). The amplitudes of $\delta^{18} \mathrm{O}_{s a c}$ variations were relatively low and both records show similar patterns. A significant change in inner-Caribbean surface water conditions occurred after 4.4 Ma. The $\delta^{18} \mathrm{O}_{s a c}$ amplitudes at site 1000 strongly increased from $4.4 \mathrm{Ma}$ to $3.8 \mathrm{Ma}$ (up to $1.3 \%$ ) and were considerably higher than those observed at

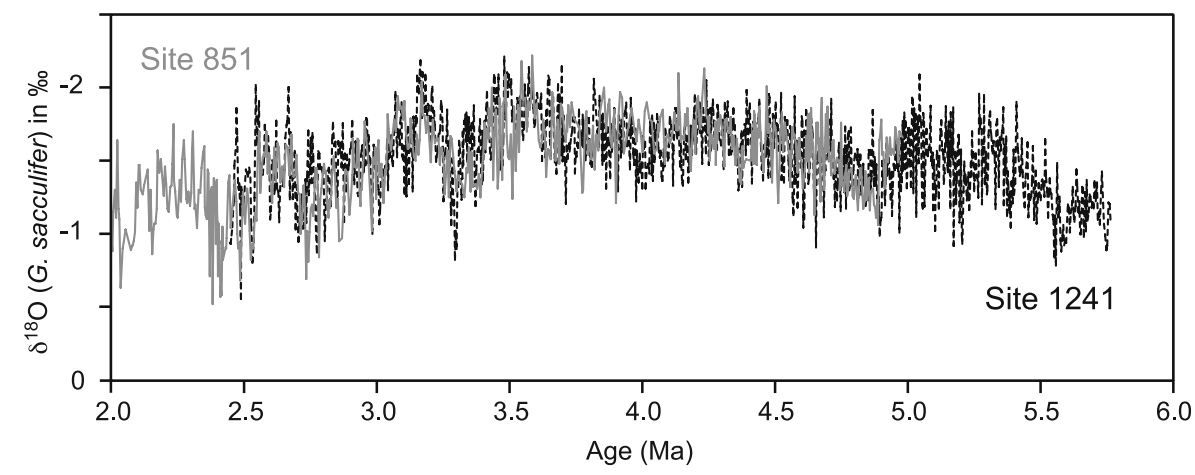

Figure 7. Comparison of $\delta^{18} \mathrm{O}$ records for the mixed layer dwelling planktonic foraminifer G. sacculifer from tropical east Pacific ODP sites 1241 (dashed line) [Steph, 2005; Steph et al., 2006] and 851 (shaded line) [Cannariato and Ravelo, 1997]. 

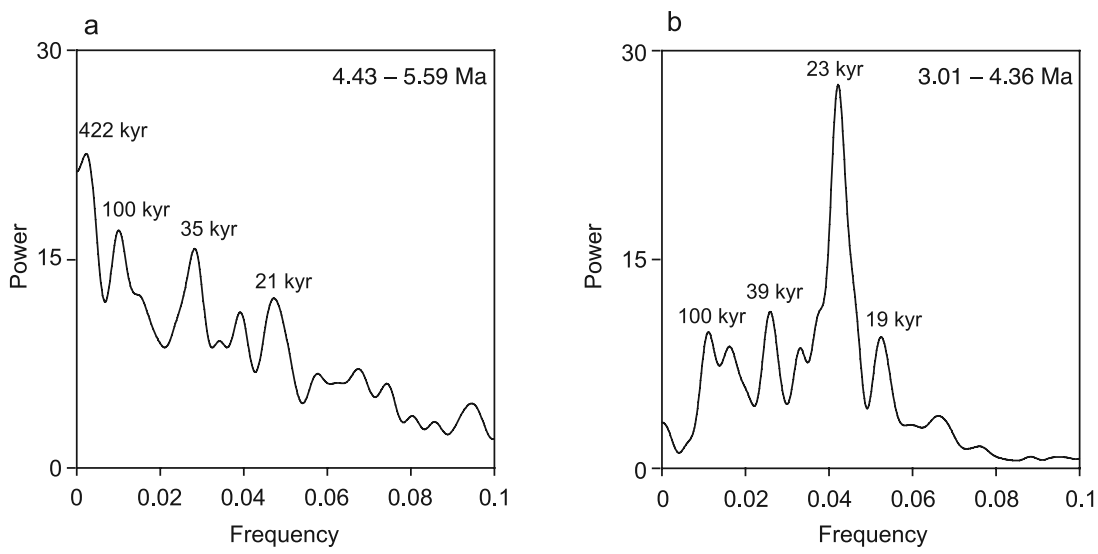

Figure 8. Spectral analyses for different time slices of the planktonic $\delta^{18} \mathrm{O}$ record (G. sacculifer) from central Caribbean site 1000. (a) Time interval from 4.43 to $5.59 \mathrm{Ma}$, when the CAS was still open for surface water exchange. The response of $\delta^{18} \mathrm{O}_{\text {sac }}$ to orbital precession was weak. Time step is $2 \mathrm{kyr}$; number of lags is $20 \%$ of the series; confidence interval is $80 \%$; bandwidth is 0.0064 . (b) Time interval from 3.01 to 4.36 Ma, when the inflow of Pacific surface waters into the Caribbean became restricted. Variations in $\delta^{18} \mathrm{O}_{s a c}$ were dominantly controlled by orbital precession. Time step is $2 \mathrm{kyr}$; number of lags is $20 \%$ of the series; confidence interval is $90 \%$; bandwidth is 0.0056 .

site 999. This increase in amplitudes is associated with the development of strong 23-kyr cycles (Figures 6 and 8). After $3.6 \mathrm{Ma}$, the difference in $\delta^{18} \mathrm{O}_{\text {sac }}$ between both sites decreased and increased again after 3.3 Ma. The strong local differences in $\delta^{18} \mathrm{O}_{\text {sac }}$ suggest a pronounced regional and temporal variability in Caribbean SSS after 4.4 Ma, if temperature fluctuations were similar at both sites.

[34] To examine the relationship between SST and SSS at site 1000 more precisely, we compared a short interval of the planktonic $\delta^{18} \mathrm{O}_{s a c}$ record $(4.6-3.8 \mathrm{Ma})$ with $\mathrm{Mg} / \mathrm{Ca}$ measurements on the same species, G. sacculifer (Figure 9). In general, high $\delta^{18} \mathrm{O}_{\text {sac }}$ values reflect low temperatures and/or high salinities. High $\mathrm{Mg} / \mathrm{Ca}$ ratios are indicative of high SST [e.g., Nürnberg et al., 1996, 2000; Nürnberg, 2000]. Here we do not present absolute $\mathrm{Mg} / \mathrm{Ca}$-derived temperatures. This will be the topic of an extended forthcoming publication (J. Groeneveld et al., The Pliocene $\mathrm{Mg} / \mathrm{Ca}$ increase in the Caribbean: Western Atlantic Warm Pool formation, salinity influence, or diagenetical overprint?, unpublished manuscript, 2005, hereinafter referred to as Groeneveld et al., unpublished manuscript, 2005), which evaluates possible influences of diagenesis and/or SSS on $\mathrm{Mg} / \mathrm{Ca}$ ratios (see auxiliary material ${ }^{1}$ ). From $4.4 \mathrm{Ma}$ to $3.8 \mathrm{Ma}$, when the progressive closure of the isthmus led to the Pacific-Caribbean salinity contrast, fluctuations in $\mathrm{Mg} / \mathrm{Ca}$ ratios, $\delta^{18} \mathrm{O}_{\text {sac }}$ and $\mathrm{NH}$ summer insolation are clearly positively correlated; for example, maxima in $\mathrm{NH}$ summer insolation are associated with high $\mathrm{Mg} / \mathrm{Ca}$ ratios (high $\mathrm{SST}$ ) and high $\delta^{18} \mathrm{O}_{s a c}$ values (high $\mathrm{SSS}$ ) at site 1000 . This implies that maxima in Caribbean mixed layer salinity occurred during warm stages. Since the effect of SST on $\delta^{18} \mathrm{O}_{\text {sac }}$ values is opposite to SSS, and the $\delta^{18} \mathrm{O}_{\text {sac }}$ temperature signal is fully compensated by the strong overprint of

\footnotetext{
${ }^{1}$ Auxiliary materials are available in the HTML. doi:10.1029/ 2004PA001092.
}

SSS, the $\delta^{18} \mathrm{O}_{\text {sac }}$ amplitudes of $1.3 \%$ indicate even larger salinity variations as if they were solely interpreted in terms of salinity. According to the $\delta^{18} \mathrm{O}$-salinity relationship for modern Caribbean surface waters (Figure 3a), such fluctuations would correspond to a change in SSS of up to 4 salinity units. We are aware that the Pliocene $\delta^{18} \mathrm{O}$-salinity relationship may have deviated from the modern one and was possibly closer to the general modern ocean $\delta^{18} \mathrm{O}$-salinity relationship $\left(1 \%{ }^{18} \mathrm{O}_{\mathrm{W}}=0.5 \mathrm{~S}\right)$ [Broecker, 1989], which would reduce the amplitude of 4 salinity units to 2.6 salinity units.

[35] It is well known that precession-related changes of the seasonal cycle at low latitudes significantly affect the strength and zonality of the trade winds and tropical SST conditions as shown by modeling experiments and paleoceanographic data [e.g., Kutzbach and Guetter, 1986; McIntyre et al., 1989]. The strong response of mixed layer signatures at site 1000 to orbital precession (23-kyr cycles) would imply low- rather than high-latitude climate forcing as the dominant trigger for changes in SST and SSS because of the absence of pronounced 41-kyr cycles. The clear deviation between the planktonic $\delta^{18} \mathrm{O}_{\text {sac }}$ record and the benthic $\delta^{18} \mathrm{O}$ record (Figures 4 and 6) also suggests strong local forcing rather than global forcing. The mixed layer water mass signatures of Caribbean sites 1000 and 999 seem to be decoupled from each other after $4.4 \mathrm{Ma}$, as planktonic $\delta^{18} \mathrm{O}_{\text {sac }}$ at site 999 reflects only weak 41-kyr cycles but shows no clear response to changes in orbital precession. During NH summer insolation maxima, large differences in $\delta^{18} \mathrm{O}_{s a c}(\sim 1.5 \%$ o $)$ suggest a very strong salinity gradient toward the north. SSS increased by up to 3 salinity units over a distance of $\sim 450 \mathrm{~km}$ (from site 999 to site 1000), indicating a pronounced hydrographic front between both sites. During NH summer insolation minima, the $\delta^{18} \mathrm{O}$ difference between sites 999 and 1000 is smallest, except for the intervals from 3.9-3.6 Ma and from 3.3$3 \mathrm{Ma}$, when differences in $\delta^{18} \mathrm{O}$ were enlarged $(0.6 \%$ ). 

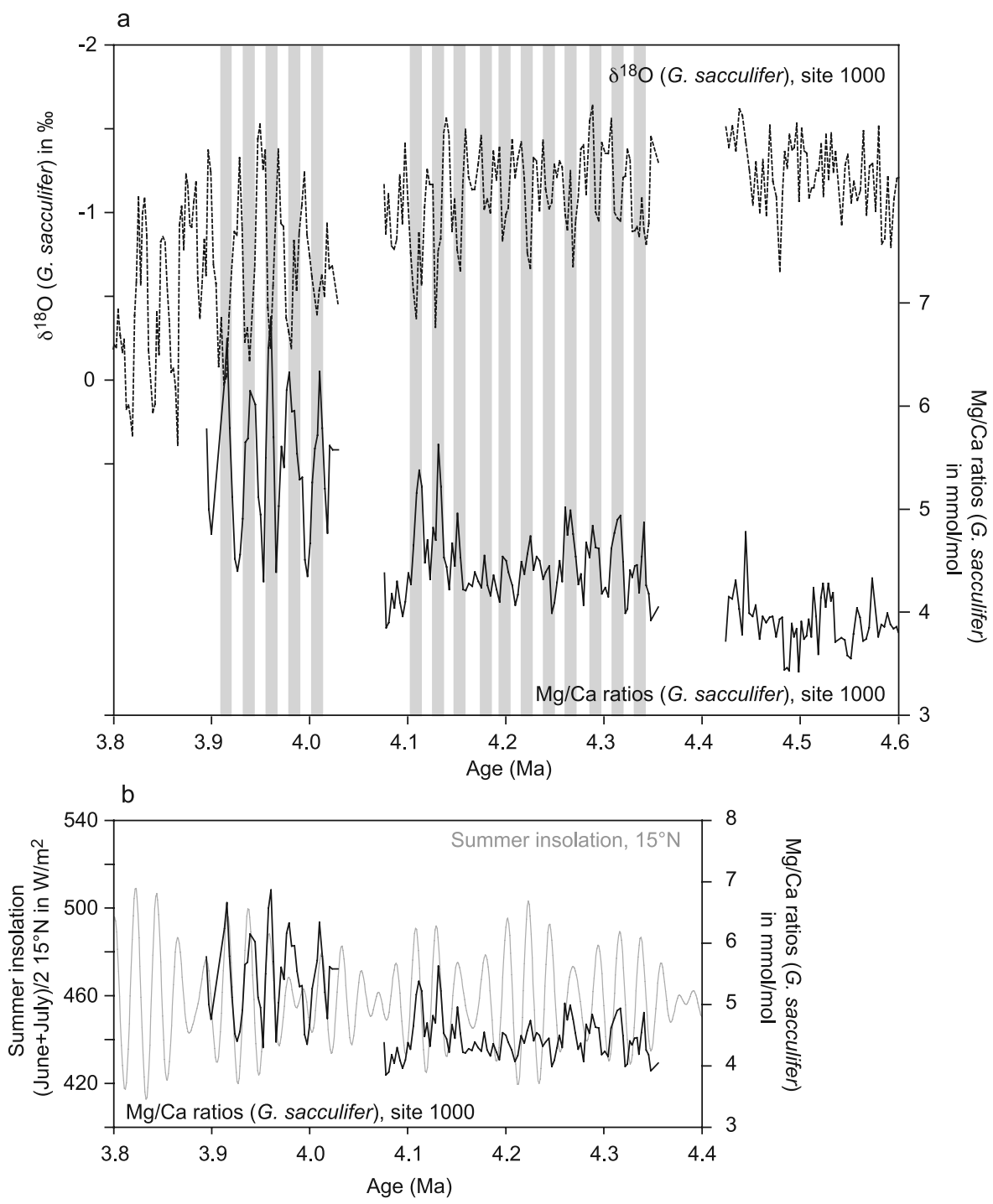

Figure 9. $\mathrm{Mg} / \mathrm{Ca}$ ratios ( $G$. sacculifer) for Caribbean site 1000 covering the time interval from $4.6 \mathrm{Ma}$ to $3.8 \mathrm{Ma}$ (Groeneveld et al., unpublished manuscript, 2005). (a) $\mathrm{Mg} / \mathrm{Ca}$ ratios (solid line) and $\delta^{18} \mathrm{O}$ G. sacculifer (dashed line) from site 1000. Shaded bars indicate the correlation of high $\mathrm{Mg} / \mathrm{Ca}$ ratios (high SST) with high $\delta^{18} \mathrm{O}$ values (interpreted as high SSS). (b) Comparison of $\mathrm{Mg} / \mathrm{Ca}$ ratios and $\mathrm{NH}$ summer insolation (June plus July/2, $15^{\circ} \mathrm{N}$ ) [Laskar et al., 1993] demonstrating that high SST are generally linked to $\mathrm{NH}$ summer insolation maxima.

[36] Insights into the Pacific-Caribbean exchange of water masses at the intermediate water level $(400-500 \mathrm{~m}$ water depth) are provided by $\delta^{18} \mathrm{O}$ records of the deep dwelling foraminifer $G$. crassaformis $\left(\delta^{18} \mathrm{O}_{\text {cras }}\right)$ which span the critical time interval from 4.05-3.8 Ma (Figure 10). The comparison of Caribbean $\delta^{18} \mathrm{O}_{\text {cras }}$ records (sites 999 and $1000)$ reflects similar $\delta^{18} \mathrm{O}$ amplitudes $(\sim 0.7 \%)$ and temporal variations between 4.05 and 3.8 Ma. The $\delta^{18} \mathrm{O}_{\text {cras }}$ values at site 999 are on average $\sim 0.25 \%$ higher than at site 1000. Another remarkable feature of the Caribbean $\delta^{18} \mathrm{O}_{\text {cras }}$ records is the lack of the long-term increase in $\delta^{18} \mathrm{O}$ that marks the Caribbean $\delta^{18} \mathrm{O}_{s a c}$ records (Figures 6 and 10). Moreover, the $\delta^{18} \mathrm{O}$ amplitudes of G. crassaformis are only half the $\delta^{18} \mathrm{O}$ amplitudes of $G$. sacculifer at site 1000 and the variability at precessional periodicities is as weak as at site 999. Accordingly, the correlation between $\delta^{18} \mathrm{O}_{\text {cras }}$ and $\delta^{18} \mathrm{O}_{\text {sac }}$ at site 1000 is low $(\mathrm{r}=0.22)$. This indicates, as expected, that the general increase in Caribbean SSS after 4.2 Ma, as well as the strong precession-related variability in salinity were restricted to shallower water depths.

[37] The $\delta^{18} \mathrm{O}_{\text {cras }}$ record of Pacific site 1241 only spans the time interval from 3.7 to $3.9 \mathrm{Ma}$, because we did not find enough specimens of $G$. crassaformis for isotope analyses in samples covering the interval from 3.9 to $4.05 \mathrm{Ma}$. The $\delta^{18} \mathrm{O}_{\text {cras }}$ values at site 1241 are similar to those from the Caribbean (Figure 10). In general, absolute values appear within the range of Caribbean $\delta^{18} \mathrm{O}_{\text {cras }}$ fluctuations. However, the short-term fluctuations $(<40 \mathrm{kyr})$ and associ- 


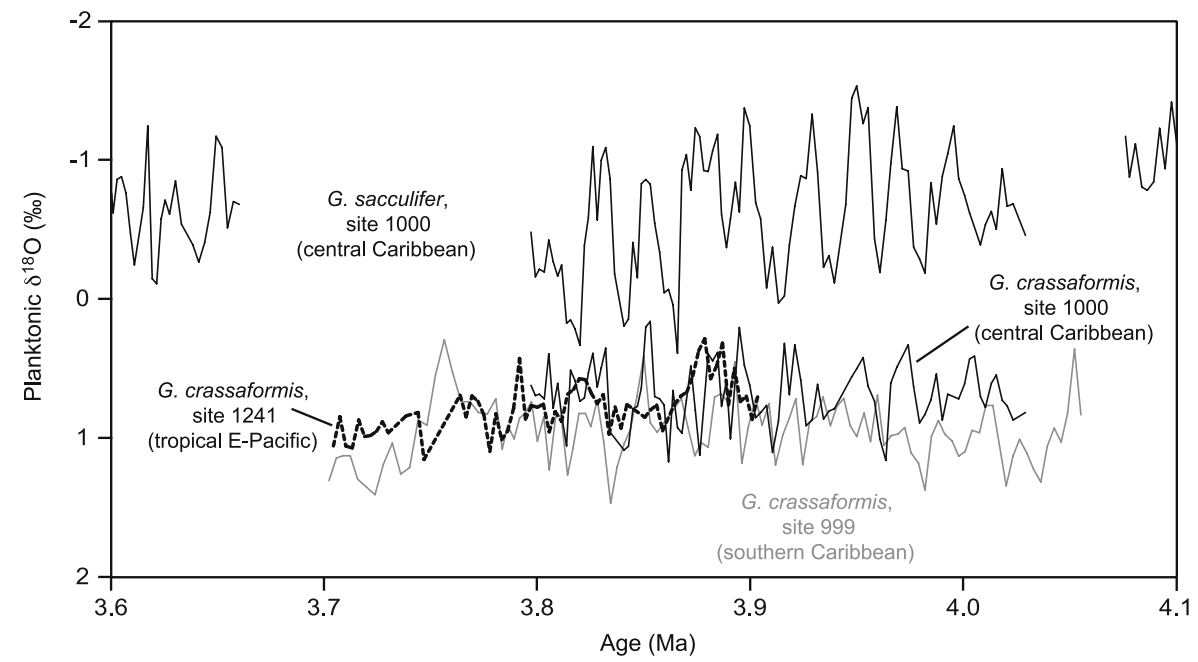

Figure 10. The $\delta^{18} \mathrm{O}$ records of the deep dwelling planktonic foraminifera G. crassaformis (bottom curves) compared to the $\delta^{18} \mathrm{O}$ record of the mixed layer dweller G. sacculifer from central Caribbean site 1000 (top curves) for the time interval from 3.7 Ma to 4.05 Ma. Solid line indicates central Caribbean site 1000 (top curves); shaded line indicates southern Caribbean site 999; dashed line indicates tropical east Pacific site 1241 .

ated amplitudes are higher at Caribbean sites than at Pacific site 1241 .

\section{What Controls Caribbean SSS and SST During the Pliocene?}

[38] The local differences in Caribbean SSS as well as the presence of strong 23-kyr cycles in SSS and SST at site 1000 , paralleling the progressive closure of the CAS, raise several questions concerning the climate forcing mechanisms. There is no doubt that tectonic feedbacks and atmosphere-upper ocean interactions are responsible for the observed patterns, but the mechanisms to be considered are manifold. This includes long-term tectonic processes like the shoaling of the CAS, the uplift of the northern Andes, as well as interactions between insolation, tropical wind field, hydrological cycle, ocean surface currents, and El Niño-Southern Oscillation (ENSO) fluctuations, affecting Caribbean surface hydrography also on shorter timescales. These processes will be discussed below, whereas analysis of our model experiment shall help to evaluate their significance.

\subsection{Flow Direction Through the CAS During the Early Pliocene}

[39] On the basis of simple dynamical principles Nof and Van Gorder [2003] conclude that the net transport through the CAS would be westward in the absence of NADW production. Significant formation of NADW, however, could reverse the direction of the flow through the gateway. Paleoceanographic evidence from deep-sea sediment records points to significant NADW formation since the middle Miocene [e.g., Keller and Barron, 1983; Woodruff and Savin, 1989; Wright and Miller, 1996; Frank et al., 2002]. Deep-water formation strengthened during the late Miocene, approaching modern values by $\sim 6 \mathrm{Ma}$ [Delaney,
1990; King et al., 1997; Billups, 2002; Lear et al., 2003]. During the early to middle Pliocene (4.4-3.1 Ma), the rate of thermohaline overturn in the North Atlantic probably exceeded modern conditions [e.g., Raymo et al., 1996; Billups, 2002], allowing a net eastward transport through the CAS [cf. Nof and Van Gorder, 2003].

[40] Recent model studies consistently suggest an eastward upper ocean $(<800 \mathrm{~m})$ transport through the CAS [Nisancioglu et al., 2003; Prange and Schulz, 2004; Klocker et al., 2005]. In these models, invasion of lowsaline Pacific water into the Atlantic through the open gateway results in a weakened NADW formation compared to the present-day, but not in a complete collapse of deepwater circulation in the Atlantic Ocean.

[41] Further evidence for an eastward CAS upper ocean throughflow comes from the comparison of $\delta^{18} \mathrm{O}_{\text {sac }}$ records from tropical east Pacific sites 851 and 1241 (Figures 1 and 7); [Steph, 2005; Steph et al., 2006]. Site 1241 is located close to the remaining passages in the gateway, and site 851 is positioned $2700 \mathrm{~km}$ westward of site 1241 . Both sites are under the influence of the NECC. The comparison of their $\delta^{18} \mathrm{O}_{\text {sac }}$ records indicates that surface mixed layer conditions were almost identical at both sites between 5 and $2.5 \mathrm{Ma}$, considering the error range of isotope analyses and stratigraphy. The absence of $\delta^{18} \mathrm{O}_{\text {sac }}$ gradients between sites 1241 and 851 contradicts a significant flow of saline Caribbean surface waters into the Pacific.

[42] In CCSM2/T31x3a, the flow through the CAS is eastward at all depths except for a thin $(<12 \mathrm{~m})$ Ekmandominated surface layer, in which the flow follows the direction of the trade winds. Driven by the steric sea level difference between the Pacific and Atlantic oceans, the net volume transport through the gateway into the Atlantic Ocean amounts to $12 \mathrm{~Sv}$, which is comparable to results from other model studies [see Nisancioglu et al., 2003; Prange and Schulz, 2004]. The flow of low-saline Pacific 


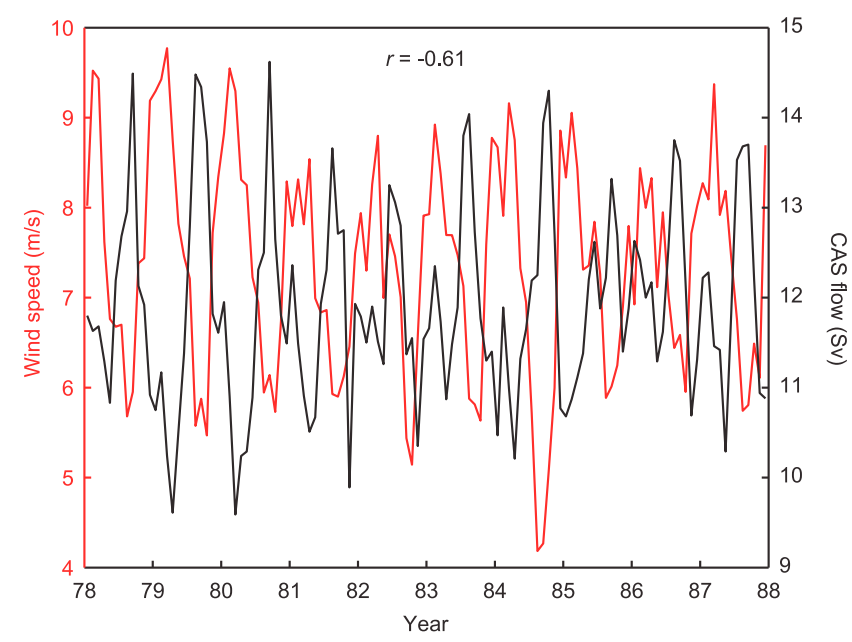

Figure 11. Ten-year time series (years 1978-1988 of the synchronous integration phase) for surface wind speed averaged over the area of the CAS and the southwestern Caribbean $\left(84^{\circ} \mathrm{W}-74^{\circ} \mathrm{W}, 8^{\circ} \mathrm{N}-14^{\circ} \mathrm{N}\right)$ (red) and net volume transport through the CAS (black) in CCSM2/T31x3a (monthly values). The linear correlation coefficient is $r=$ -0.61 . Tick marks on the time axis are set at the beginning of each year.

water through the CAS reduces SSS in the southwestern Caribbean by $\sim 1$ salinity unit compared to the present-day control run. This salinity anomaly is advected into the northern North Atlantic, affecting deepwater formation there. With an open gateway, maximum meridional overturning in the North Atlantic is $2 \mathrm{~Sv}$ smaller than in the CCSM2/T31x3a control run (12 Sv versus $14 \mathrm{~Sv}$ ). Only a small upper ocean salinity gradient $(\sim 0.2$ salinity units) is simulated between Caribbean sites 999 and 1000, whereas the difference between the Caribbean and the Pacific (site 1241 ) is $\sim 1$ salinity unit (Figure $2 b$ ). Comparing these results with the $\delta^{18} \mathrm{O}_{s a c}$ records (Figure 6) suggests that the modeled surface hydrography reflects a situation after 4.7 Ma (i.e., when the Pacific-Atlantic water exchange was already restricted to a considerable degree), even though the sill depth of the CAS may be too deep in the numerical experiment. However, the strong inner-Caribbean salinity gradient that appears in the sedimentary record after 4.2 Ma cannot be simulated by CCSM2/T31x3a, most probably for the following reasons: (1) the salinity contrast of the water masses that feed the Caribbean (i.e., Pacific water from the west and Atlantic water from the east) is too small in the model (see section 3.2), (2) the oceanic grid resolution is too coarse to resolve regional frontal systems in the Caribbean and/or local features of the throughflow dynamics, (3) the width of the CAS was smaller during the final phase of the closure than the horizontal grid resolution of the ocean model, hence the injection of Pacific water into the Caribbean is too diffuse in the model.

[43] The CAS throughflow exhibits a pronounced seasonal variability in CCSM2/T31x3a. In most years, the eastward volume transport is largest in summer and smallest in winter/spring (Figure 11). These seasonal fluctuations are closely linked to variations in wind stress over the Central
American region and can be related to seasonal shifts of the ITCZ. During winter/spring, when the ITCZ reaches its southernmost position, the influence of the northeast trades is strongest within the gateway region. The resulting wind stress works against the steric pressure head, leading to a reduction of the total CAS throughflow.

[44] In summary, we infer that the net transport through the gateway was directed from the Pacific into the Caribbean during the Pliocene time interval from 5.5-3 Ma, when NADW formation was already strong and when the sill was shallow enough to affect surface water exchange [Keigwin, 1982; Haug et al., 2001a]. This result can be put into a broader Cenozoic context. Comprehensive climate model simulations (utilizing an earlier version of CCSM) for the Eocene, where wide Panamanian and Tethys seaways have been taken into account, indicate westward circumequatorial flow, i.e., transport through the CAS from the Atlantic to the Pacific [Huber and Sloan, 2001; Huber et al., 2003]. A net volume transport from the Atlantic to the Pacific was also found by Von der Heydt and Dijkstra [2006] in a model simulation with Oligocene-like continental configuration. Upon switching to an (early) Miocene-like model setup, the authors found a flow reversal (i.e., net eastward transport) through the CAS. This flow reversal was related to the widening of Southern Ocean passages and closing of the Tethys seaway.

\subsection{Constriction of the Gateway}

[45] For the early Miocene preisthmian phase, paleobathymetrical reconstructions from benthic foraminiferal assemblages suggest a sill depth of $\sim 2000 \mathrm{~m}$ [Duque-Caro, 1990], allowing for free exchange between Pacific and Atlantic water masses down to intermediate depths [Keller and Barron, 1983]. By $12 \mathrm{Ma}$, the sill shoaled to a water depth of $\sim 1000 \mathrm{~m}$, blocking the deeper flow through the Panama-Costa Rica Strait [Duque-Caro, 1990; Coates et al., 1992]. The first recorded intermingling of terrestrial faunas between North and South America between 8 and 9.3 Ma [Webb, 1985; Marshall, 1988] suggests the existence of an extended archipelago in Central America since the late Miocene. From $\sim 12-6 \mathrm{Ma}$, the Panama sill shoaled to $\sim 200 \mathrm{~m}$ water depth [Duque-Caro, 1990], but deeper leakages in the Panama isthmian strait $(200-500 \mathrm{~m}$ water depth) may have persisted as indicated by bathyal benthic foraminifera from the Chargres Formation [Collins et al., 1996].

[46] More recently, several studies documented that the progressive closure of the CAS reached a critical threshold for profound changes in ocean circulation and climate between 4.7 and 4.2 Ma [Haug and Tiedemann, 1998; Haug et al., 2001a]. Similar planktonic $\delta^{18} \mathrm{O}_{\text {sac }}$ values at Caribbean and equatorial east Pacific sites imply that prior to $4.7 \mathrm{Ma}$, all sites were bathed in the same surface water mass. This was most likely an extension of the Pacific NECC and/or Equatorial Undercurrent (Figure 1) that traveled through the gateway as a thin jet and became entrained into the western boundary current on the Caribbean side of the gateway. However, the fact that these sites were linked via an ocean current does not exclude that a gradient in water mass properties as a whole between the 
tropical east Pacific and the Caribbean already existed prior to $4.7 \mathrm{Ma}$.

[47] After 4.2 Ma, divergence of $\delta^{18} \mathrm{O}_{\text {sac }}$ records from the Caribbean and the tropical east Pacific (Figure 6) indicates that the progressive closure of the gateway restricted surface water exchange, reducing the inflow of low-salinity Pacific water masses into the Caribbean. Decreasing export of lowsalinity Pacific surface waters may have contributed to a decrease in SSS at Pacific sites 851 and 1241 with respect to Caribbean sites 999 and 1000. At the same time, the zonal net atmospheric transport of water vapor from the Atlantic/ Caribbean into the Pacific probably increased SSS in the Caribbean and decreased SSS in the tropical east Pacific, suggesting that the atmospheric freshwater flux into the Pacific exceeds the low-salinity return flow from the Pacific into the Caribbean. Constriction of the throughflow also led to the establishment of an inner-Caribbean SSS gradient, as it favored the SSS increase toward the north. In contrast to central Caribbean site 1000, the southern site 999 appears to be permanently affected by the throughflow of low-salinity surface waters as indicated by generally lower $\delta^{18} \mathrm{O}_{\text {sac }}$ values and amplitudes (Figure 6). The simplest explanation is that site 999 was located closer to the remaining passages of the CAS [Savin and Douglas, 1985; Duque-Caro, 1990; Collins et al., 1996]. Site 1000, however, was more affected by saline surface water probably originating from the tropical Atlantic (like today), which was entrained into the western boundary flow of the Caribbean Current (see section 7.4). This makes the position of site 1000 more sensitive to changes in the volume transport through the gateway and associated expansions of Pacific low-salinity water, as indicated by a high variability in $\delta^{18} \mathrm{O}_{s a c}$ values after 4.4-4.2 Ma.

[48] If the freshwater balance of atmospheric export from the Atlantic/Caribbean and oceanic import from the Pacific via the CAS tipped the scale for SSS changes in the Caribbean, the divergence between Pacific and Caribbean $\delta^{18} \mathrm{O}_{\text {sac }}$ records since $4.7-4.2 \mathrm{Ma}$ does not necessarily imply that the sill depth was shallower than the habitat depth of G. sacculifer. A change in the volume transport of surface waters in response to a narrowing of the gateway could also explain the long-term increase in Caribbean SSS, although a leakage in the gateway deeper than the habitat depth of $G$. sacculifer may still have existed. If the Panama sill was shallower than $100 \mathrm{~m}$ since $4.2 \mathrm{Ma}$, as suggested by Haug et al. [2001a], we may also expect different water mass signatures at the intermediate water level between the Pacific and Caribbean sites. The comparison of PacificCaribbean $\delta^{18} \mathrm{O}_{\text {cras }}$ records displays no clear offset and may argue for a deeper leakage at the intermediate water level (Figure 10). Otherwise, similar Pacific-Caribbean $\delta^{18} \mathrm{O}_{\text {cras }}$ values do not exclude a shallow sill depth for the following reason: considering the modern temperature and salinity distribution at 400-500 $\mathrm{m}$ water depth provides similar $\delta^{18} \mathrm{O}_{\mathrm{C}}$ values at sites 1241 and 999 when applying equations 3 and 4 (see section 4 ). Thus the $\delta^{18} \mathrm{O}_{\text {cras }}$ records provide no clear evidence for a sill depth shallower than the habitat depth of $G$. crassaformis.

[49] Among other mechanisms, sea level fluctuations on orbital timescales associated with changes in the Antarctic ice volume may have influenced water depth in the passage, volume transport across the sill, and thus Caribbean SSS. During the early Pliocene (prior to the intensification of $\mathrm{NHG}$ ) orbital-scale variability in benthic $\delta^{18} \mathrm{O}$ records was relatively small and fluctuated predominantly on 41-kyr cycles with $\delta^{18} \mathrm{O}$ amplitudes of up to $0.5 \%$ [e.g., Lisiecki and Raymo, 2005]. This would correspond to deepwater temperature changes of $\sim 2^{\circ} \mathrm{C}$ or to sea level changes on the order of $45 \mathrm{~m}$ [Fairbanks and Matthews, 1978], neglecting long-term changes in the isotopic composition of the Antarctic ice sheet, which would modify the $\delta^{18} \mathrm{O}$-sea level relationship [Mix and Ruddiman, 1984]. It is most likely that the $\delta^{18} \mathrm{O}$ signal reflects a combination of temperature and eustatic sea level change. Sea level changes on 23-kyr cycles are assumed to have been even smaller because benthic isotope records show no clear response to precessional forcing. Hence it is rather unlikely that precessional fluctuations in global sea level triggered significant changes in the throughflow. Precession-induced changes in the Caribbean salinity gradient thus most likely responded to variations in insolation, tropical wind field, and oceanography rather than to tectonic changes or global sea level fluctuations.

[50] A remarkable return to lower SSS at site 1000 with $\delta^{18} \mathrm{O}$ values similar to those at site 999 marks the time interval from 3.6-3.3 Ma (Figure 6). This diminishing gradient may reflect a repeated long-term intensification of the throughflow associated with a change in the width or depth of the gateway, although we cannot exclude other factors as mentioned below. A significant eustatic sea level rise at $3.6 \mathrm{Ma}$ is improbable, because benthic $\delta^{18} \mathrm{O}$ records indicate no general decrease in global ice volume (Figure 4). However, the end of this event at 3.3 Ma is paralleled by an increase in global ice volume (culminating in MIS-M2 and MIS-MG2), and thus by a sea level drop.

\subsection{Mountain Uplift and River Runoff}

[51] The Neogene uplift of the Andes presumably caused extensive changes in South American climate and winddriven oceanic surface circulation by reorganizing the pattern of atmospheric circulation and the hydrological cycle [Hay, 1996; Mix et al., 2003]. However, the timing and consequences for climate and ocean circulation, possibly responding to critical thresholds in the uplift history, are poorly constrained. The uplift of the Andes established a barrier for the southeast trade winds that is considered to have influenced the hydrological cycle. Today, this orographic interception results in a rain shadow on the western side and enhanced precipitation on the eastern side of the subequatorial northern Andes south of $3^{\circ} \mathrm{S}$, forming a major source for the Amazon River. North of $3^{\circ} \mathrm{S}$, within the range of the Intertropical Convergence Zone (ITCZ), both sides receive heavy rainfall [Montgomery et al., 2001]. A review of quantitative paleoelevation estimates [Gregory-Wodzicki, 2000] suggests that the Eastern Cordillera of the central Andes attained no more than half of the modern elevation by $\sim 10 \mathrm{Ma}$ and implies uplift on the order of 2000-3500 m since the late Miocene. Major uplift of the Colombian Andes has been assessed to have occurred at a later stage, reaching $\sim 40 \%$ of their modern elevation by $\sim 4 \mathrm{Ma}$ and $\mathrm{a}$ 
modern height by $\sim 2.7 \mathrm{Ma}$. This timing corresponds roughly to changes in the erosion history of the Andes as detected in Atlantic sediment sequences from ODP Leg 154 (Ceara Rise). Increasing Amazon River supply and changes in clay mineralogy indicate major uplift phases from 9-8 Ma [Dobson et al., 1997] and since 4.6 Ma [Curry et al., 1995] as well as a substantial regional climate change [Tiedemann and Franz, 1997; Harris and Mix, 2002]. Thus the late Miocene and early Pliocene may represent the most dynamic episode of uplift in the northeastern Andes. According to Hoorn et al. [1995], the late Miocene paleogeographic evolution of northern South America redirected the outflow of the Orinoco River from the Caribbean into the Atlantic. This should have resulted in a net increase in Caribbean SSS, although enhanced drainage into the Atlantic and subsequent freshening of the Guyana Current may have partly compensated the Caribbean SSS increase. The influence of the Magdalena River discharge on late Neogene Caribbean water mass signatures is unknown. We surmise that an enhanced Pacific inflow of low-salinity waters would overprint the fluvial signatures and the freshwater plume would be diverted eastward. At this point, we cannot exclude a fluvial freshening at site 999. If at all, the influence of the Magdalena River may have become more important during the final closure of the Isthmus.

\subsection{Atlantic-Caribbean Surface Water Exchange}

[52] Consistent with previous model studies [e.g., Nisancioglu et al., 2003; Prange and Schulz, 2004], the CCSM2/T31x3a experiment suggests that the constriction of Pacific water flow through the CAS caused an intensification of the Guyana and North Brazil currents (not shown). This change in current strengths would favor the flow of equatorial Atlantic water masses through the southernmost Lesser Antilles Passages rather than forcing the advection of water masses from the North Atlantic subtropical gyre [Johns et al., 2002] (see section 2).

[53] To track early Pliocene changes in $\delta^{18} \mathrm{O}$ signatures of water masses that entered the Caribbean via the Guyana Current and left the Caribbean through the Florida Straits, we compared planktonic $\delta^{18} \mathrm{O}_{\text {sac }}$ records from site 925 (Ceara Rise) [Billups et al., 1998] and site 1006 (Bahama Bank) with those from the Caribbean (Figure 12). Today, Caribbean surface waters originate from the equatorial Atlantic (Caribbean Water, CW, 0-80 m) and from the North Atlantic subtropical gyre (Subtropical Under Water, SUW, $80-180 \mathrm{~m}$ ). The salinity of SUW is $\sim 1$ salinity unit higher than the salinity of CW (Figure 13). Comparing sites 925 and 1000, we monitor the influence of equatorial western Atlantic surface waters at the position of Caribbean site 1000 . At site 1006, upper ocean water masses consist of two main components: the Caribbean outflow via the Florida Current and the western boundary flow of the subtropical gyre, which contributes approximately $10 \%$ to the Florida Current [Leaman et al., 1995]. Hence site 1006 should display general changes in Caribbean salinities.

[54] A comparison of sites 925 and 1000 indicates that equatorial western Atlantic $\delta^{18} \mathrm{O}_{s a c}$ values were similar to Caribbean values prior to $4.4 \mathrm{Ma}$ (Figure 12). After $4.4 \mathrm{Ma}$ the Caribbean trend toward higher $\delta^{18} \mathrm{O}$ values is not reflected at site 925. In contrast, $\delta^{18} \mathrm{O}$ values (site 925) decreased at $4.4 \mathrm{Ma}$ and remained at a significantly lower level until 3.2 Ma. During times of extreme Caribbean salinity maxima (e.g., $3.8-4 \mathrm{Ma}$ ), the $\delta^{18} \mathrm{O}$ values at site 1000 were $\sim 1.5 \%$ o higher than at site 925 . Although allowing for higher temperatures at site 925, the large difference clearly suggests lower salinities in the equatorial western Atlantic. This excludes the transfer of water masses via the Guyana Current as a major Caribbean salinity source. We attribute the maxima in Caribbean SSS to an enhanced inflow of Atlantic surface waters originating from the subtropical gyre. This contradicts model results that suggest enhanced inflow via the Guyana Current (see above).

[55] The $\delta^{18} \mathrm{O}_{\text {sac }}$ differences between sites 1000 and 1006 are expected to display modifications in surface water signatures on their route through the Caribbean basins. For a comparison with site 1000 , we established $\delta^{18} \mathrm{O}_{\text {sac }}$ records with a time resolution better than $1 \mathrm{kyr}$ for two short time intervals from $\sim 4.5-4.6 \mathrm{Ma}$ and $\sim 4.0-4.1 \mathrm{Ma}$ [Reuning, 2005; Reuning et al., 2006]. These two intervals cover the full range of orbital-scale $\delta^{18} \mathrm{O}$ amplitude fluctuations prior to and after the critical threshold in the closure history of the CAS. The comparison between sites 1000 and 1006 (Figure 12) is probably biased by minor stratigraphic uncertainties, as age control at site 1006 is solely based on biostratigraphy [Kroon et al., 2000, Reuning, 2005; Reuning et al., 2006]. The $\delta^{18} \mathrm{O}_{\text {sac }}$ values at site 1006 are on average $\sim 0.4 \%$ o higher than at site 1000 prior to the restriction of Pacific surface water inflow into the Caribbean (4.54.6 Ma). If temperatures were similar at both sites (like today), SSS at the exit of the Caribbean would have been $\sim 0.8$ salinity units higher. Such an increase may have resulted from salinity enrichment of Caribbean surface waters caused by evaporation during their journey from site 1000 to site 1006, and from the admixture of high-salinity waters from the subtropical Atlantic gyre.

[56] The interval from $\sim 4.0-4.1 \mathrm{Ma}$, unfortunately, includes a data gap at site 1000 (see section 5). Nevertheless, both $\delta^{18} \mathrm{O}_{\text {sac }}$ records show similar values, and the amplitudes at site 1006 correspond to those observed at site 1000 between 4.2 Ma and $4 \mathrm{Ma}$. Another important feature at site 1006 is the strong response of the $\delta^{18} \mathrm{O}_{\text {sac }}$ record to orbital precession and the positive correlation to planktonic $\mathrm{Mg} / \mathrm{Ca}$-ratios [Reuning et al., 2005] as observed at site 1000 . We therefore conclude that the observed changes in Caribbean salinity are transported into the Atlantic via the Florida Current, influencing the transfer of salt into the source regions of NADW formation, and perhaps the variability of thermohaline overturn also on precessional periods. The presence of a semiprecessional component in the $\delta^{18} \mathrm{O}_{\text {sac }}$ record at site 1006, which was not recorded at site 1000, is interpreted as an overprint from low-salinity waters originating in the Gulf of Mexico [Reuning et al., 2006].

\subsection{What Is the Link Between Tropical Wind Field and Caribbean Hydrography?}

[57] Early Pliocene changes in the tropical wind field and associated patterns of ocean currents are considered impor- 


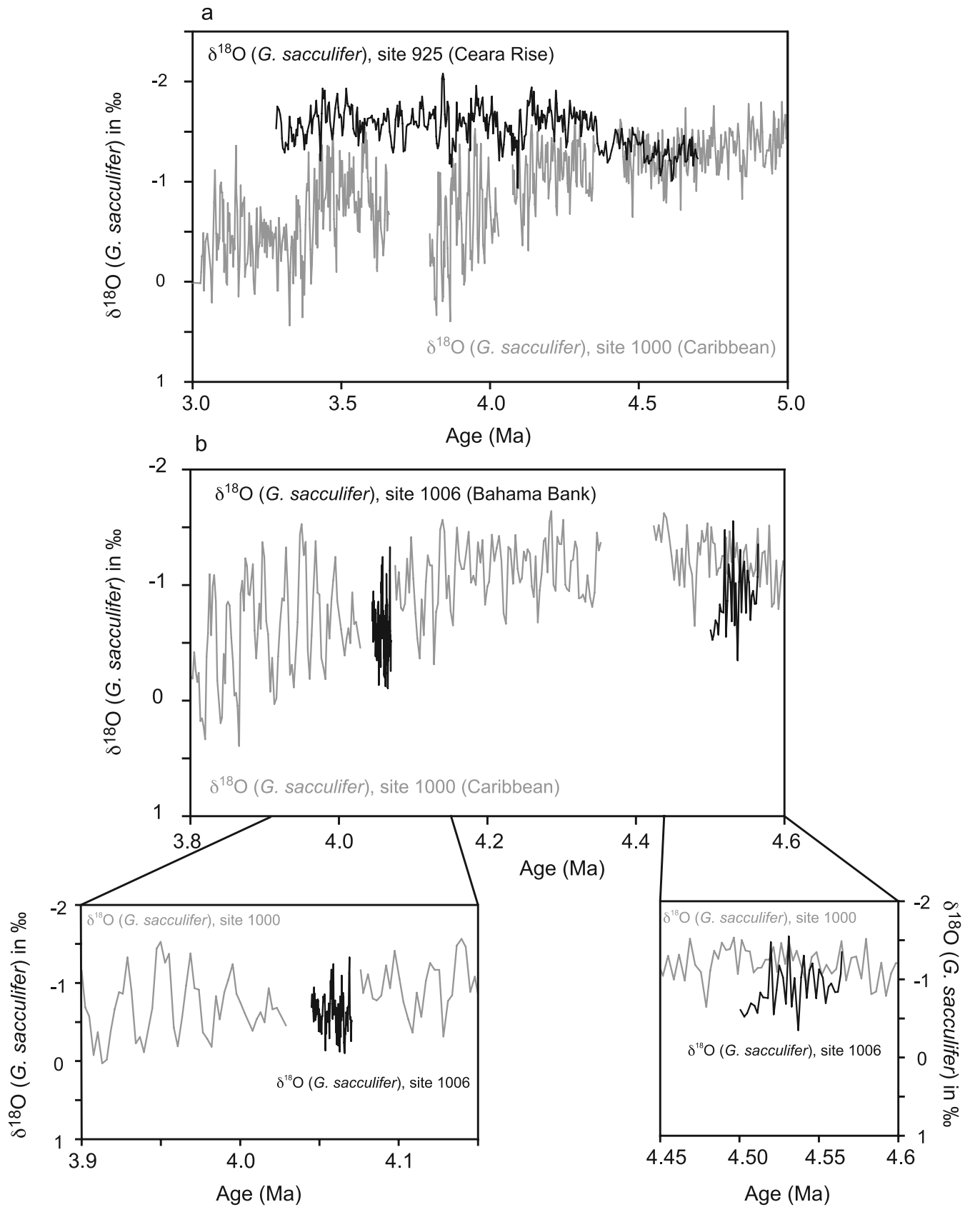

Figure 12. Comparison of planktonic $\delta^{18} \mathrm{O}$ records (G. sacculifer) from Caribbean site 1000 (this study) and Atlantic sites (a) 925 and (b) 1006. The $\delta^{18} \mathrm{O}_{s a c}$ records from sites 1000 (shaded line) and 925 (equatorial western Atlantic, Ceara Rise, solid line) [Billups et al., 1998, 1999] are shown. After 4.4 Ma, $\delta^{18} \mathrm{O}_{s a c}$ values at site 925 are significantly lower than at Caribbean site 1000 . (b) The $\delta^{18} \mathrm{O}_{s a c}$ record from site 1000 (shaded line) compared to $\delta^{18} \mathrm{O}_{s a c}$ from site 1006 (western Great Bahama Bank, Caribbean outflow region, solid line) for two short time intervals (4-4.1 Ma and 4.5-4.6 Ma) [Reuning, 2005; Reuning et al., 2006]. The $\delta^{18} \mathrm{O}_{s a c}$ values were generally higher at site 1006 in the older time interval, whereas in the younger part, $\delta^{18} \mathrm{O}_{s a c}$ reveals similar values and amplitudes at both sites.

tant parameters to explain the observed inner-Caribbean variations in upper water mass signatures. Migrations of the ITCZ and the associated precipitation pattern strongly influence SSS in the tropics. Thus a general shift of the tropical rain belt should have an imprint on SSS. In comparison to its modern average position at $\sim 6^{\circ} \mathrm{N}$ (Figure 1), the ITCZ is expected to be located farther north during the late Miocene to early Pliocene $\left(\sim 10^{\circ} \mathrm{N}\right)$ [Flohn, 1981], as the lack of an NH ice cap strengthened the thermal asymmetry between both hemispheres. A weaker NH poleequator temperature gradient would have pulled the ITCZ northward. This is consistent with the fact that early to midPliocene climate was warmer than today and less variable than during the late Pliocene and Pleistocene, because of the 


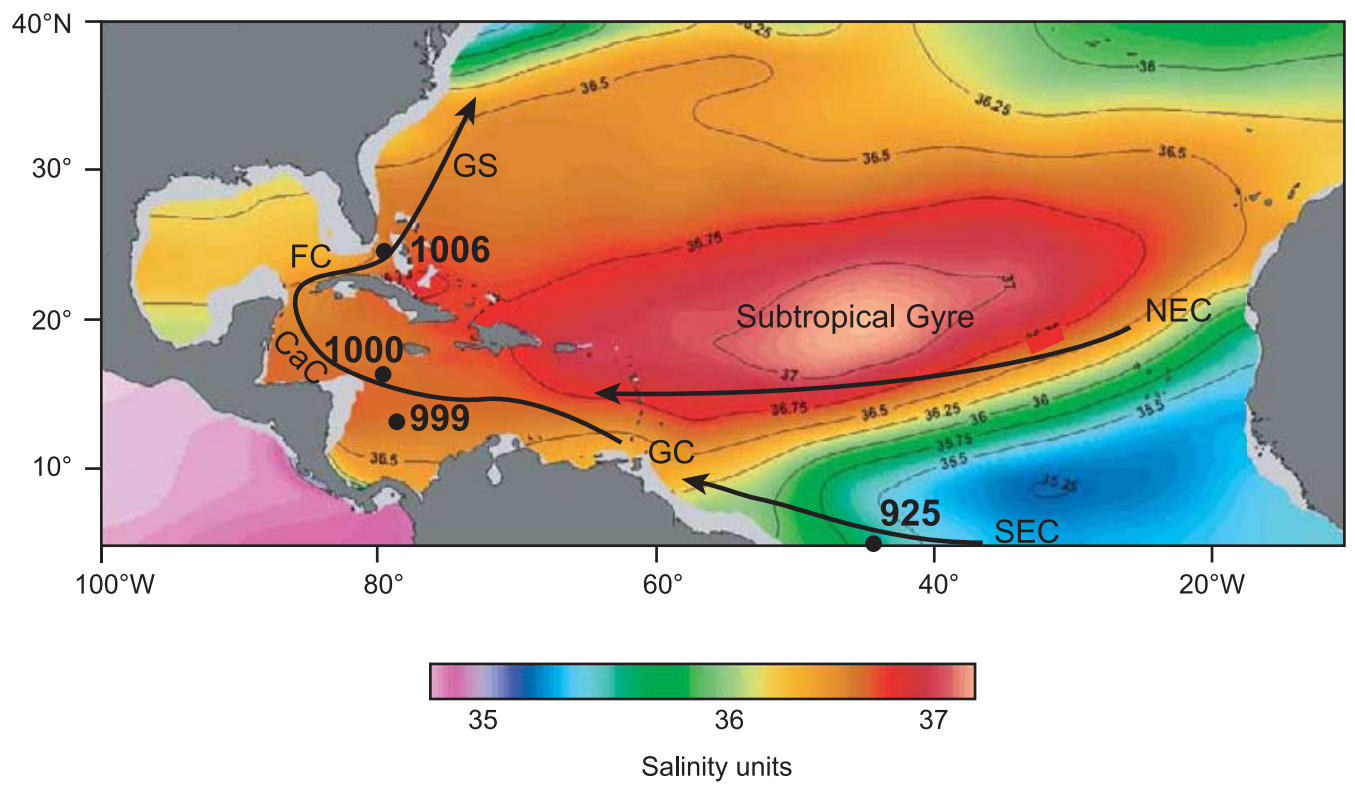

Figure 13. Annual salinity at $150 \mathrm{~m}$ water depth (using data from Conkright et al. [2002] and the program Ocean Data View by R. Schlitzer, 2005, available at http://odv.awi-bremerhaven.de/) and major surface current systems of the tropical Atlantic/Caribbean. Abbreviations are $\mathrm{CaC}$, Caribbean Current; FC, Florida Current; GC, Guyana Current; GS, Gulf Stream; NEC: North Equatorial Current; and SEC, South Equatorial Current. Circles indicate locations of ODP sites 925, 999, 1000, and 1006.

absence of large fluctuations in global ice volume [Crowley, 1991; Tiedemann et al., 1994; Mix et al., 1995]. Microfaunal evidence from mid-Pliocene sediment records suggests warmer SST of $3-7^{\circ} \mathrm{C}$ in middle to high latitudes and no significant temperature difference in the tropics with respect to the present [e.g., Dowsett et al., 1996]. Moreover, intensification of the Gulf Stream enhanced North Atlantic heat piracy via strengthened cross-equatorial heat transport and intensified thermohaline overturn after $\sim 4.6 \mathrm{Ma}$ [Crowley, 1992; Mikolajewicz and Crowley, 1997; Haug and Tiedemann, 1998; Prange and Schulz, 2004]. Southern Ocean SST reconstructions from silicoflagelates [Whitehead and Bohaty, 2003] indicate a temperature decrease after $\sim 4.2 \mathrm{Ma}$, supporting the hypothesis of enhanced northern hemisphere heat piracy. At first glance, the latter process suggests that shallowing of the CAS would induce a northward migration of the ITCZ, which is also supported by CCSM2/T31x3a (Figure 14). Dust flux records off northwest Africa, however, imply that the latitudinal summer position of the ITCZ over the eastern Atlantic has remained essentially in place during the Pliocene [Tiedemann et al., 1989]. As the position of the ITCZ strongly depends on atmospheric pressure gradients created by thermal differences, the relative stable position in the eastern Atlantic may result from continental influence, since northwest Africa attains a surface temperature much higher than the adjacent ocean, which stabilizes the minimum in surface pressure [Philander et al., 1996].

[58] In contrast, strong support for an early Pliocene southward shift of the ITCZ comes from studies on Atlantic and Pacific changes in the tropical wind field and surface hydrography [Hovan, 1995; Cannariato and Ravelo, 1997;

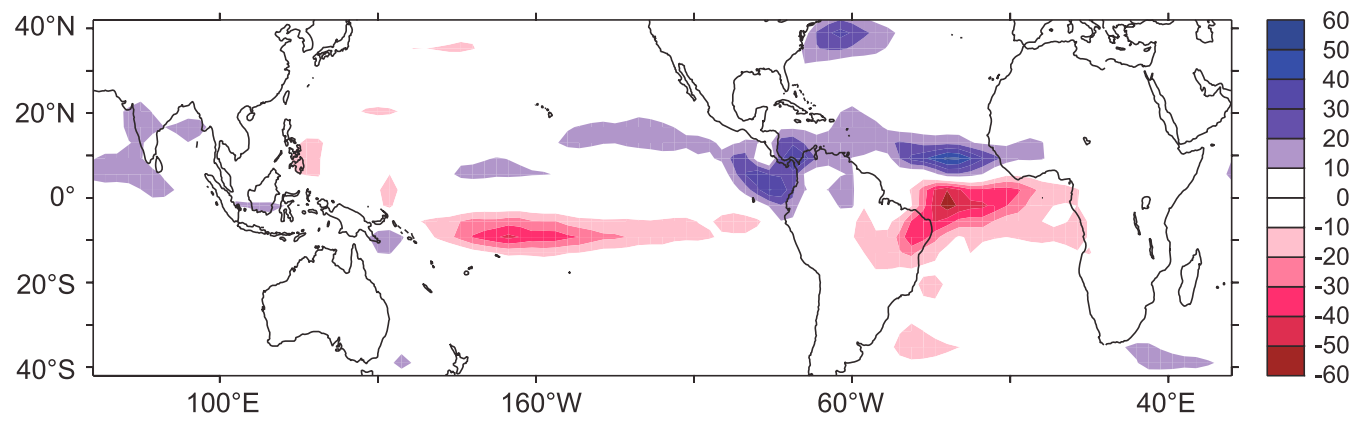

Figure 14. Difference in annual mean tropical precipitation $(\mathrm{cm} / \mathrm{yr})$ between CCSM2/T31x3a control run and experiment with open CAS indicating a northward shift of the ITCZ in response to the seaway closure. 
Chaisson and Ravelo, 1997; Billups et al., 1999]. Farrell et al. [1995] noted a dramatic decrease in carbonate and opal accumulation as well as a distinct southward shift in the locus of maximum opal accumulation rates in the eastern tropical Pacific at $\sim 4.4 \mathrm{Ma}$. These changes were accompanied by a decrease of the thermocline depth in the eastern tropical Pacific [Cannariato and Ravelo, 1997; Steph, 2005; Steph et al., 2006]. The observed shift in the geographical patterns of biogenic sediment accumulation and the shoaling of the thermocline may be indicative of changes in the tropical wind field. This is consistent with a weakening of the southeast trade winds between 5 and $4 \mathrm{Ma}$ and a southward shift of the ITCZ in the east Pacific as deduced from eolian grain size and flux studies [Hovan, 1995]. These changes document the reorganization of tropical Pacific circulation most probably in response to the restriction of the CAS, as these shifts occurred along with the development of the Atlantic-Pacific salinity contrast. In the tropical Atlantic, major changes in surface hydrography at 4.4-4.0 Ma [Chaisson and Ravelo, 1997; Norris, 1998] were also linked to a southward movement of the ITCZ [Billups et al., 1999].

[59] In the Caribbean, a Pliocene displacement of the ITCZ is elusive, since changes in the volume transport through the gateway probably overprinted changes in Caribbean surface water signatures that may have resulted from a southward shift of the tropical rain belt. However, the general pattern of latitudinal salinity changes in the Caribbean would rather be in line with a southward than with a northward shift of the ITCZ. Prior to $4.4 \mathrm{Ma}$, planktonic $\delta^{18} \mathrm{O}$ values were higher at site 1006 than at Caribbean sites 999 and 1000 (Figure 12). After 4.4 Ma, high and similar $\delta^{18} \mathrm{O}$ values characterized the northern sites $1006\left(\sim 24^{\circ} \mathrm{N}\right)$ and $1000\left(\sim 16^{\circ} \mathrm{N}\right)$, while $\delta^{18} \mathrm{O}$ values at southern Caribbean site $999\left(\sim 12^{\circ} \mathrm{N}\right)$ were generally lower. This southward shift in the inner-Caribbean salinity gradient with lower salinities at site 999 could be consistent with a southward movement of the tropical rain belt (ITCZ) closer to site 999 (Figures 1, 6, and 12). The observed pattern would also be in line with a sea surface freshening in the northwestern tropical Atlantic $\left(\sim 4^{\circ} \mathrm{N}\right)$ at $4.4 \mathrm{Ma}$, as indicated by a step-like $0.2 \%$ decrease in planktonic $\delta^{18} \mathrm{O}$ at site 925 [Billups et al., 1999] (Figure 12).

[60] On shorter timescales, the presence of dominant 23-kyr cycles in Caribbean SSS and SST suggests lowlatitude climate forcing to have played a crucial role in modulating surface hydrography after 4.4-4.2 Ma. However, the short-term variability of Caribbean surface water signatures cannot convincingly be explained by latitudinal shifts of the ITCZ, considering a paleosummer position south of site 1000. Several studies suggest that the latitudinal position of the ITCZ is sensitive to changes in the seasonality of insolation associated with the precession band of Milankovitch forcing [e.g., Haug et al., 2001b]. If $\mathrm{NH}$ insolation becomes more seasonal, the heat capacity of $\mathrm{NH}$ summer insolation is at a maximum and pulls both the ITCZ and the high-precipitation belt to the north. Hence we infer that maxima in NH summer insolation are associated with maxima in Caribbean SST and with minima in SSS along the rain belt of the ITCZ. Assuming the most likely scenario, namely the ITCZ to appear always south of site $1000\left(\sim 16^{\circ} \mathrm{N}\right)$, raises fundamental problems in explaining the observed variability in Caribbean SST and SSS. In this case, high SST should correlate with low SSS when the ITCZ approaches the position of site 1000 during NH summer insolation maxima. However, the observed maxima in SST at site 1000 correspond to maxima in SSS during NH summer insolation maxima. Assuming a more northerly position of the ITCZ, crossing site 1000 twice during a full precession cycle, should have induced semiprecession cycles in SSS. However, the planktonic $\delta^{18} \mathrm{O}_{\text {sac }}$ fluctuations at site 1000 provided no spectral evidence for the existence of semiprecession cycles. The extreme case, assuming a summer position of the ITCZ always north of site 1000 , could provide the observed correlation between high temperatures and high salinities at site 1000 , but would be in conflict with the data from site 1006 (Figure 12). High SST and high SSS at site 1000 may have occurred during NH summer insolation maxima, when the ITCZ and the tropical rain belt reached their northernmost position (closer to site 1006). This, on the other hand, would imply low SSS and high SST at site 1006, which is not the case [Reuning et al., $2005,2006]$. At both sites, $\delta^{18} \mathrm{O}_{s a c}$ values and amplitudes are similar and $\mathrm{Mg} / \mathrm{Ca}$ ratios are positively correlated to the $\delta^{18} \mathrm{O}$ records. Thus latitudinal fluctuations in the tropical rain belt cannot explain the observed coupling between Caribbean SSS and SST. Moreover, we would not expect that spatial changes in the precipitation/evaporation ratio induce planktonic $\delta^{18} \mathrm{O}_{s a c}$ amplitudes of up to $1.3 \%$ at sites 1000 and 1006, considering the habitat depth of G. sacculifer (see section 4). Hence the observed Caribbean pattern of SSS and SST suggests another forcing mechanism most probably associated with changes in volume transport through the gateway.

[61] In order to prove a potential control of the CAS throughflow on Caribbean hydrography, correlation maps have been calculated, taking advantage of a strong interannual and interdecadal variability of both oceanic parameters in CCSM2/T31x3a (Figure 15). On the decadal timescale, variations in the throughflow account for $\sim 65 \%(r=0.8)$ of upper ocean salinity variability in the Caribbean at site 1000 (Figure 15a). Moreover, anomalously strong throughflow is associated with subsurface cooling in the western parts of the Caribbean (Figure 15b).

[62] To clarify the lead-lag or cause-and-effect relationship between Panamanian throughflow and Caribbean hydrographic changes, we calculated a Caribbean salinity index by averaging annual mean salinity over the top $110 \mathrm{~m}$ in the surrounding area of site 1000 (see Figure 15b). A lag-correlation analysis between the salinity index and CAS throughflow suggests that Caribbean salinity changes follow variations of the throughflow by $1-2$ years (see Figure 15c). Note that the modeled interannual/interdecadal variations in Caribbean salinity are much smaller than salinity changes inferred from the $\delta^{18} \mathrm{O}_{s a c}$ data. This discrepancy can be attributed to different timescales (interannual to interdecadal in the model experiment versus Milankovitch in the sedimentary record); that is, salinity fluctuations in the Caribbean would be larger if CAS throughflow anomalies were more persistent. 

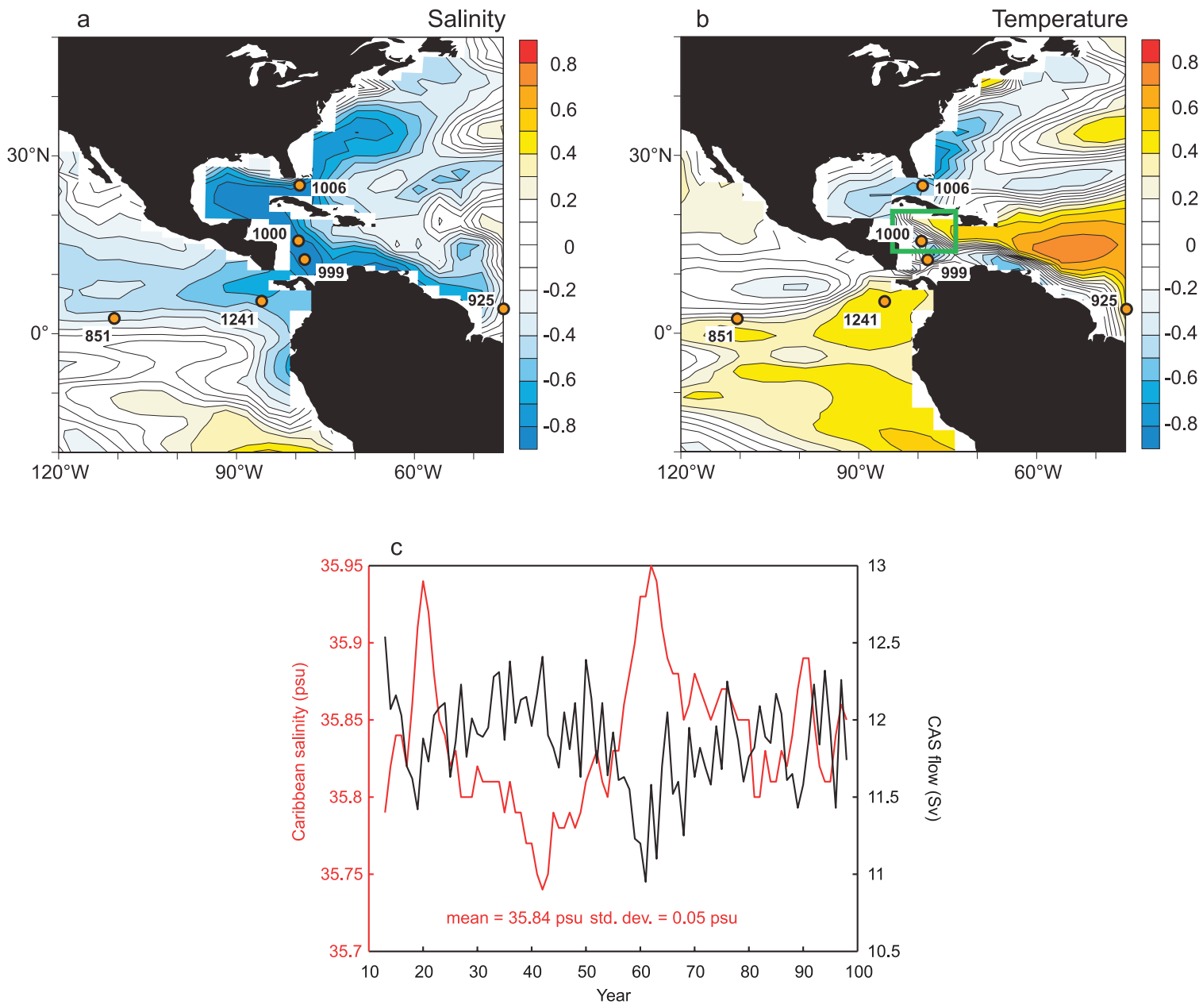

Figure 15. Correlation between net CAS throughflow and hydrographic quantities averaged over the top $110 \mathrm{~m}$ in CCSM2/T31x3a. (a) Salinity and (b) potential temperature. All time series are filtered by a 9-year boxcar average. Positions of ODP sites discussed in this study are indicated. (c) Annual mean Caribbean salinity averaged over the area marked in Figure $15 \mathrm{~b}$ and over the top $110 \mathrm{~m}$ (red) and net CAS throughflow (black) in CCSM2/T31x3a. Lag-correlation between the salinity and throughflow shows that Caribbean salinity changes follow variations of the throughflow by $1-2$ years.

[63] With reorganization of Atlantic and Pacific surface water circulation after $\sim 4.4 \mathrm{Ma}$, precession-driven variations in the tropical wind field may have exerted a stronger influence on Caribbean surface hydrography by modifying the Pacific-Caribbean and Atlantic-Caribbean surface water exchange. The development of pronounced 23-kyr cycles in Caribbean SST and SSS paralleled the development of the Atlantic-Pacific salinity contrast. This indicates that a reduction in the volume transport of Pacific surface waters through the gateway made the Caribbean more sensitive for precession-driven changes in ocean-atmosphere interactions. At the intermediate water level, Caribbean $\delta^{18} \mathrm{O}$ records of the deep dwelling planktonic foraminifer $G$. crassaformis are very similar at sites 999 and 1000, and the variability at precessional periodicities is strongly reduced with respect to the mixed layer at site 1000 (Figure 10). This suggests that the pronounced precession-related variability in salinity was restricted to shallower water depths.

[64] As discussed in section 7.1, the influence of the northeast trade winds within the gateway region is strongest during winter, when the ITCZ reaches its southernmost position. This favors the wind-driven transport of surface water toward the west and weakens the Pacific inflow into the Caribbean. In contrast, stronger southeast trades and a more northern position of the ITCZ during summer tend to strengthen the throughflow (Figure 11).

[65] Since the average annual position of the ITCZ during the early Pliocene was most likely north of its present position, it should have favored rather than weakened the throughflow. A more northern average annual position of the ITCZ in combination with low seasonality (when aphelion occurs at summer solstice) may have strengthened the Pacific inflow, as the northeast trade winds did not extend into the gateway region. The associated northward expansion of the southeast trades (or southwest monsoon north of the equator) would have promoted a surface flow from the Pacific into the Caribbean. When perihelion occurred at summer solstice (NH summer insolation maximum, winter insolation minimum), seasonality was enhanced and the winter position of the ITCZ may have 
a
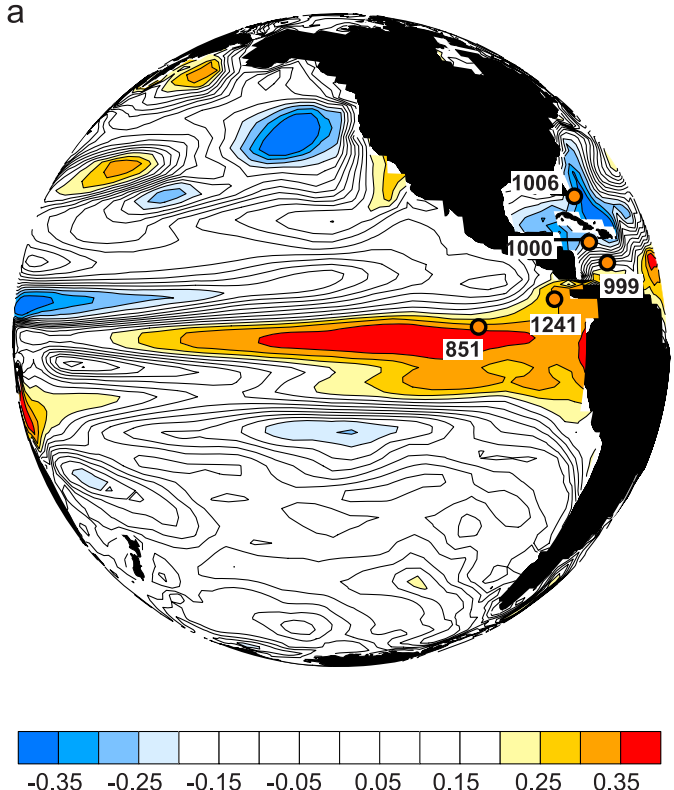

b
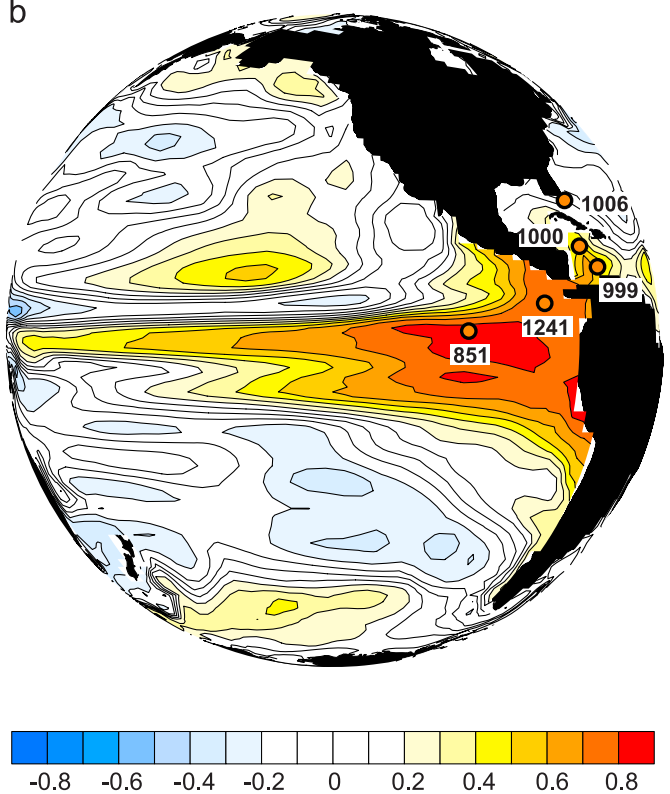

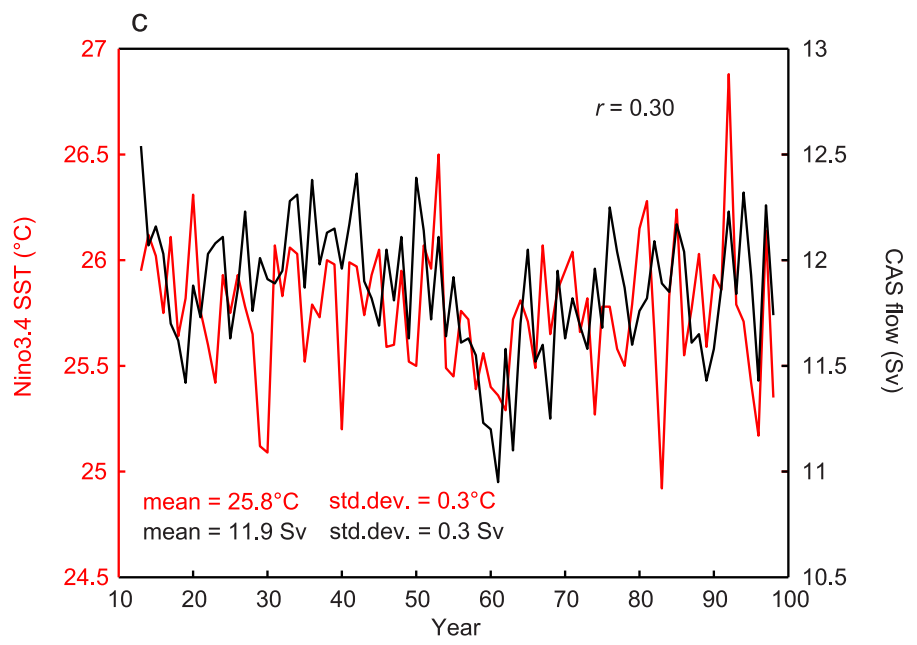

Figure 16. Correlation between annual mean sea surface height and (a) annual CAS throughflow and (b) annual mean Niño-3.4 SST in CCSM2/T31x3a. Colored contour levels are significant at the 95\% level. Positions of ODP sites discussed in this study are indicated. (c) Annual mean Niño-3.4 SST (red) and annual mean CAS throughflow (black). The linear correlation coefficient $r=0.30$ is significant at the 99\% level (based on conservative $z$ test).

approached a southern position critical for reducing the Pacific inflow into the Caribbean. A reduction in the net annual throughflow when perihelion was aligned with summer solstice may have strengthened the westward flow of Atlantic surface waters from the subtropical gyre, resulting in SST and SSS maxima at sites 1000 and 1006. Southern Caribbean site 999 probably did not register these changes as it remained under the influence of low-salinity surface waters entering from the Pacific.

[66] Further analysis of the CAS throughflow variability in CCSM2/T31x3a actually supports the above inference that net volume transport through the CAS is negatively correlated with the influx of high-saline surface waters from the North Atlantic subtropical gyre into the Caribbean. Correlation of annual throughflow values with sea surface elevation indicates a weakening/strengthening of the westward flow between Hispaniola and the South American continent when the CAS throughflow is anomalously strong/weak (Figure 16a). The correlation map further reveals a strong relation between annual throughflow and sea level height in the eastern tropical Pacific.

\subsection{Links to El Niño-Southern Oscillation (ENSO) Fluctuations}

[67] Today, El Niño-Southern Oscillation is a major source of interannual climate variability with the strongest impact on the equatorial east Pacific ocean-atmosphere 
system. In a simple coupled ocean-atmosphere model Clement et al. [1999, 2000] suggested that precessioninduced changes of the seasonal cycle influence the longterm behavior of ENSO, which in turn has the potential to modulate variations in ocean circulation and climate. These results are consistent with paleoclimate records preserved in New Guinea corals, which show a clear response of ENSO variability to seasonal insolation changes associated with orbital precession [Tudhope et al., 2001]. Both studies demonstrate that the southeast trades weaken when aphelion falls in boreal summer or autumn (as in present day), favoring the development of warm El Niño events. Vice versa, when perihelion occurs in boreal summer or autumn (as during the mid-Holocene), the southeast trade winds strengthen, and inhibit the development of warm El Niño anomalies. Evidence for a reduced mid-Holocene El Niño activity is provided by paleoclimatic studies of Ecuador Lake records [Rodbell et al., 1999], coral records from the West Pacific [Gagan et al., 1998] and pollen records from northern Australian lakes [McGlone et al., 1992].

[68] Modern El Niño events are associated with several changes in the equatorial eastern Pacific ocean-atmosphere system. The NECC strengthens, SST and precipitation increase, the thermocline deepens, sea level height increases, and the ITCZ moves equatorward. The modern difference in steric height between El Niño and La Niña events amounts to ca. $30 \mathrm{~cm}$ in the equatorial east Pacific [Philander, 1990]. Given that CAS throughflow is largely driven by a steric pressure head, it is tempting to hypothesize that long-term changes in the ENSO state had the potential to control the influx of Pacific water into the Caribbean during the middle Pliocene.

[69] In CCSM2/T31x3a, the correlation pattern between annual throughflow and sea level height (Figure 16a) closely resembles the corresponding ENSO signal in the tropical Pacific (Figure 16b). The modeled annual mean Niño-3.4 SST indeed significantly correlates to the CAS throughflow (Figure 16c). The linear correlation coefficient $r$ between these two quantities is 0.30 and can be increased considerably by smoothing the time series of Niño-3.4 SST and CAS throughflow (e.g., for a 5-year boxcar average we calculate $r=0.41$ ). We suggest that the relation between ENSO and CAS throughflow is even more pronounced for longer (i.e., Milankovitch) timescales. Furthermore, it is worth noting that the effect of ENSO on interannual CAS throughflow variability is likely to be underestimated in CCSM2/T31x3a, since the model has a relatively anemic ENSO. In both the present-day CCSM2/T31x3a control run and the experiment with open CAS, the standard deviation of annual mean Niño-3.4 SST is only half the one calculated from modern observational data (i.e., $0.64^{\circ} \mathrm{C}$ for the period 1950-2005). Moreover, the model-ENSO exhibits a maximum at around 2 years in the power spectrum rather than the observed broader spectral peak between 3 and 7 years. The presence or absence of the CAS has no significant effect on ENSO dynamics in CCSM2/T31x3a. In summary, the model results suggest a pivotal role of the ENSO state in regulating the CAS throughflow.

[70] Accordingly, changes in Pliocene ENSO may have amplified precessional variations in the CAS throughflow because the Pacific-Atlantic gradient of sea surface topography regulated the amount of throughflow into the Atlantic. Enhanced El Niño activity during minima in $\mathrm{NH}$ summer insolation is expected to have increased the volume transport of Pacific surface waters into the Caribbean via an increase in the steric height, whereas SSS of eastern equatorial Pacific surface waters was additionally lowered by enhanced precipitation. When aphelion occurred at summer solstice, El Niño-induced increases in east Pacific sea level height and reduced influence of northeast trade winds in the gateway region (section 7.5) acted in concert. This combination should have strengthened the Pacific inflow of low-salinity surface waters into the Caribbean. When perihelion occurred at summer solstice, changes in ENSO state and tropical wind patterns should have weakened Pacific inflow. These ENSO-related ocean-atmosphere couplings and their effect on the volume transport through the gateway (enhanced throughflow during $\mathrm{NH}$ summer insolation minima) would be in line with our observations (see sections 6 and 7.5).

[71] Molnar and Cane [2002], Philander and Fedorov [2003] and others propose that the early to mid-Pliocene Pacific was characterized by a "permanent El Niño-like state." Such a scenario would contribute to a generally enhanced sea level difference between the tropical east Pacific and the North Atlantic. However, paleoceanographic evidence from site 1239 off the coast of Ecuador suggests considerable variability in surface productivity on precessional cycles, indicative of changes in upwelling and wind strength [Mix et al., 2003]. Thus, although Pliocene climate may have been biased toward an El Niño-like mode of operation, this does not exclude long-term ENSO climate variability forced by the precessional cycle [cf. Huber and Caballero, 2003].

\section{Conclusions}

[72] Pliocene planktonic $\delta^{18} \mathrm{O}$ records from the Caribbean (sites 999, 1000), the western Atlantic (sites 925, 1006), and the tropical east Pacific (sites 851, 1241) have been used to reconstruct variations in Pacific-Caribbean and AtlanticCaribbean surface water exchange in response to the progressive closure of the CAS. Major changes occurred between 4.7 and 4.2 Ma, when divergence of Pacific and Caribbean $\delta^{18} \mathrm{O}_{\text {sac }}$ records points to an increase in Caribbean SSS that was probably linked to a reduction of the volume transport of surface water masses through the CAS. The new data is consistent with the hypothesis that the closure of the CAS affected the ocean-atmosphere-climate system through increased heat and salt transport to high northern latitudes [e.g., Haug and Tiedemann, 1998; Prange and Schulz, 2004]. The main conclusions include the following:

[73] 1. Comparison of paired planktonic $\delta^{18} \mathrm{O}$ and $\mathrm{Mg} / \mathrm{Ca}$ data (G. sacculifer) from central Caribbean site 1000 suggests salinity fluctuations on precessional periodicities with amplitudes of $\sim 2.6$ salinity units $(1.3 \%$ change in $\delta^{18} \mathrm{O}$ ) after $4.4 \mathrm{Ma}$. These amplitudes represent minimum changes in salinity, as $\delta^{18} \mathrm{O}$ and $\mathrm{Mg} / \mathrm{Ca}$ data are positively correlated. Maxima in SSS and SST correspond to preces- 
sional maxima in $\mathrm{NH}$ summer insolation. At the intermediate water level, the Caribbean $\delta^{18} \mathrm{O}$ records of the deep dwelling planktonic foraminifer $G$. crassaformis are very similar at sites 999 and 1000 and the variability at precessional periodicities is strongly reduced with respect to the mixed layer at site 1000. This suggests that the pronounced precession-related variability in salinity was restricted to shallower water depths.

[74] 2. Differences in planktonic $\delta^{18} \mathrm{O}_{s a c}$ between sites 999 and 1000 identify a strong variability in Caribbean salinity gradients toward the north after $4.4 \mathrm{Ma}$. The more southern position of site 999 was generally more affected by the admixture of low-salinity Pacific surface waters. Expansions of Pacific low-salinity water influenced the more northern site 1000 only during minima in $\mathrm{NH}$ summer insolation, when $\delta^{18} \mathrm{O}_{\text {sac }}$ differences between sites 999 and 1000 were smallest. Salinity differences (up to $1.5 \%$ in $\delta^{18} \mathrm{O}$ ) were largest during $\mathrm{NH}$ summer insolation maxima. This is interpreted to reflect a stronger influence of relatively warm and saline Atlantic surface waters at Caribbean site 1000 during times of reduced volume transport through the CAS.

[75] 3. Atlantic-Caribbean differences in planktonic $\delta^{18} \mathrm{O}_{s a c}$ (sites 925,1000 ) exclude the transfer of water masses from the Guyana Current through the southernmost Lesser Antilles Passages as a main source for the observed Caribbean salinity maxima. This suggests the North Atlantic subtropical gyre to be the major supplier for Caribbean high-salinity water masses during maxima in $\mathrm{NH}$ summer insolation.

[76] 4. Similar planktonic $\delta^{18} \mathrm{O}_{s a c}$ values and amplitudes at Caribbean site 1000 and site 1006 (located within the Caribbean outflow region) reflect that the observed changes in Caribbean salinity are transported into the Atlantic via the Florida Current. This in turn should have influenced the transfer of salt into the North Atlantic source regions of deep water formation, thereby affecting the convection and strength of the thermohaline overturn perhaps also on precessional periods.

[77] 5. The weak response of Caribbean SSS and SST at site 1000 to changes in orbital obliquity in combination with a strong response to orbital precession suggests low-latitude climate forcing to have played a crucial role in modulating the interbasin surface water exchange through ocean-atmosphere interactions after $4.4 \mathrm{Ma}$. Supported by climate model results, we surmise that changes in the volume transport through the gateway were mainly driven by precession-induced variations in the tropical wind field and ENSO-related changes of sea level height in the tropical east Pacific. Latitudinal shifts of the ITCZ on precessional periods cannot explain the observed coupling between Caribbean SSS and SST after 4.4 Ma, considering a paleosummer position of the ITCZ slightly north of the modern one. In this case high SST should correlate with low SSS when the ITCZ approaches the position of site 1000 during $\mathrm{NH}$ summer insolation maxima, which is opposite to our observations.

[78] Acknowledgments. We thank H. Kinkel, A. Schmittner, D. Crudeli, and A. Sturm for discussions and criticism and L. Haxhiaj, U. Nielsen, and A. Jesußek for technical assistance. The manuscript was significantly improved by the thoughtful comments of J. R. Toggweiler and an anonymous reviewer. This research used samples and data provided by the Ocean Drilling Program, which is sponsored by the U.S. National Science Foundation and participating countries under management of Joint Oceanographic Institutions. The climate model experiments have been performed on the IBM pSeries 690 Supercomputer of the "Norddeutscher Verbund für Hoch- und Höchstleistungsrechnen" (HLRN). Funding for this research was provided by the Deutsche Forschungsgemeinschaft through projects Ti 240/7 and Ti 240/12 (the latter being part of the DFG-Research Unit, FOR 451: Impact of Gateways on Ocean Circulation, Climate, and Evolution at Kiel University) and through the DFG Research Center Ocean Margins at the University of Bremen (RCOM0440).

\section{References}

Backman, J., and I. Raffi (1997), Calibration of Miocene nannofossil events to orbital tuned cyclostratigraphy from Ceara Rise, Proc. Ocean Drill. Program Sci. Results, 154, 83-100.

Barker, S., M. Greaves, and H. Elderfield (2003), A study of cleaning procedures used for foraminiferal $\mathrm{Mg} / \mathrm{Ca}$ paleothermometry, Geochem. Geophys. Geosyst., 4(9), 8407, doi:10.1029/ 2003GC000559.

Berger, W. H., and G. Wefer (1996), Expeditions into the past: Paleoceanographic studies in the South Atlantic, in The South Atlantic: Present and Past Circulation, edited by G. Wefer et al., pp. 363-410, Springer, New York.

Berggren, W. A., and C. D. Hollister (1974), Paleogeography, paleobiogeography, and the history of circulation of the Atlantic Ocean, in Studies in Paleoceanography, edited by W. W. Hay, Spec. Publ. Soc. Econ. Paleontol. Mineral., 20, 126-186.

Bickert, T., W. B. Curry, and G. Wefer (1997), Late Pliocene to Holocene (2.6-0 Ma) western equatorial Atlantic deep-water circulation: Inferences from benthic stable isotopes, Leg
154, Proc. Ocean Drill. Program Sci. Results, $154,239-254$

Billups, K. (2002), Late Miocene through early Pliocene deep water circulation and climate change viewed from the subantarctic Southern Ocean, Palaeogeogr. Palaeoclimatol. Palaeoecol., 185, 287-307.

Billups, K., A. C. Ravelo, and J. C. Zachos (1997), Early Pliocene deep-water circulation: Stable isotope evidence for enhanced Northern Component Deep Water, Proc. Ocean Drill. Program Sci. Results, 154, 319-330.

Billups, K., A. C. Ravelo, and J. C. Zachos (1998), Early Pliocene deep water circulation in the western equatorial Atlantic: Implications for high-latitude climate change, Paleoceanography, 13, 84-95.

Billups, K., A. C. Ravelo, J. C. Zachos, and R. D. Norris (1999), Link between oceanic heat transport, thermohaline circulation, and the Intertropical Convergence Zone in the early Pliocene Atlantic, Geology, 27, 319-322.

Broecker, W. S. (1989), The salinity contrast between the Atlantic and Pacific oceans dur- ing glacial time, Paleoceanography, 4, $207-$ 212.

Broecker, W. S., and G. H. Denton (1989), The role of ocean-atmosphere reorganizations in glacial cycles, Geochim. Cosmochim. Acta, 53, 2465-2501.

Bryan, K. (1988), Efficient methods for finding the equilibrium climate of coupled ocean-atmosphere models, in Physically-Based Modelling and Simulation of Climate and Climatic Change-Part I, edited by M. E. Schlesinger, pp. 567-582, Springer, New York.

Bryan, K., and L. J. Lewis (1979), A water mass model of the world ocean, J. Geophys. Res., 84, 2503-2517.

Cannariato, K. G., and A. C. Ravelo (1997), Pliocene-Pleistocene evolution of eastern tropical Pacific surface water circulation and thermocline depth, Paleoceanography, 12, 805820.

Chaisson, W. P., and A. C. Ravelo (1997), Changes in upper water-column structure at site 925 , Late Miocene-Pleistocene: Planktonic foraminifer assemblage and isotopic evidence, 
Proc. Ocean Drill. Program Sci. Results, 154, $255-268$.

Clement, A. C., R. Seager, and M. A. Cane (1999), Orbital controls on the El Niño/ Southern Oscillation and the tropical climate, Paleoceanography, 14, 441-456.

Clement, A. C., R. Seager, and M. A. Cane (2000), Suppression of El Niño during the mid-Holocene by changes in the Earth's orbit, Paleoceanography, 15, 731-737.

Coates, A. G., J. B. C. Jackson, L. S. Collins, T. M. Cronin, H. J. Dowsett, L. M. Bybell, P. Jung, and J. A. Obando (1992), Closure of the Isthmus of Panama: The near-shore marine record of Costa Rica and western Panama, Geol. Soc. Am. Bull., 104, 814-828.

Collins, L. S., A. G. Coates, W. A. Berggren, M.-P. Aubry, and J. Zhang (1996), The late Miocene Panama Isthmian Strait, Geology, 24, 687-690.

Conkright, M. E., R. A. Locarnini, H. E. Garcia, T. D. O'Brien, T. P. Boyer, C. Stephens, and J. I. Antonov (2002), World Ocean Atlas 2001: Objective analyses, data statistics, and figures [CD-ROM], documentation, 17 pp., Natl. Oceanogr. Data Cent., Silver Spring, Md. (Available at http://www.nodc.noaa.gov)

Crowley, T. J. (1991), Past $\mathrm{CO}_{2}$ changes and tropical sea surface temperatures, Paleoceanography, 6, 387-394.

Crowley, T. J. (1992), North Atlantic Deep Water cools the Southern Hemisphere, Paleoceanography, 7, 489-497.

Curry, W. B., et al. (1995), Proceedings of the Ocean Drilling Program Initial Report, vol. 154, Ocean Drill. Program, College Station, Tex.

Danabasoglu, G. (2004), A comparison of global ocean general circulation model solutions obtained with synchronous and accelerated integration methods, Ocean Modell., 7, 323-341.

Danabasoglu, G., J. C. McWilliams, and P. R. Gent (1996), Approach to equilibrium in accelerated global oceanic models, J. Clim., 9, $1092-1110$

Delaney, M. L. (1990), Miocene benthic foraminiferal $\mathrm{Cd} / \mathrm{Ca}$ records: South Atlantic and western equatorial Pacific, Paleoceanography, 5, $743-760$.

Dessier, A., and J. R. Donguy (1994), The seasurface salinity in the tropical Atlantic between $10^{\circ} \mathrm{S}$ and $30^{\circ} \mathrm{N}$ : Seasonal and interannual variations (1977-1989), Deep Sea Res., Part I, $41,81-100$.

Dobson, M. D., G. R. Dickens, and D. K. Rea (1997), Terrigenous sedimentation at Ceara Rise, Proc. Ocean Drill. Program Sci. Results, 154, 465-473.

Dowsett, H. J., J. Barron, and R. Z. Poore (1996), Middle Pliocene sea surface temperatures: A global reconstruction, Mar. Micropaleontol., 27(1/4), 13-25.

Driscoll, N. W., and G. H. Haug (1998), A short circuit in the thermohaline circulation: A cause for Northern Hemisphere glaciation?, Science, $282,436-438$.

Duplessy, J. C., P. L. Blanc, and A. W. H. Bé (1981), $\delta^{18} \mathrm{O}$-enrichment of planktonic foraminifera due to gametogenetic calcification below the euphotic zone, Science, 213 , $1247-1250$

Duque-Caro, H. (1990), Neogene stratigraphy, paleoceanography and paleobiogeography in northwest South America and the evolution of the Panama Seaway, Palaeogeogr. Palaeoclimatol. Palaeoecol., 77, 203-234.

Fairbanks, R. G. M., and R. K. Matthews (1978), The marine oxygen isotope record in Pleisto- cene coral, Barbados, West Indies, Quat. Res., $10,181-196$

Fairbanks, R. G., M. Sverdlove, R. Free, P. H. Wiebe, and A. W. H. Bé (1982), Vertical distribution and isotopic fractionation of living planktonic foraminifera from the Panama Basin, Nature, 298, 841-844.

Farrell, J. W., I. Raffi, T. R. Janecek, D. W Murray, M. Levitan, K. A. Dadey, K. C. Emeis, M. Lyle, J. A. Flores, and S. Hovan (1995), Late Neogene sedimentation patterns in the eastern equatorial Pacific Ocean, Proc. Ocean Drill. Program Sci. Results, 138, $717-$ 756.

Flohn, H. (1981), A hemispheric circulation asymmetry during late Tertiary, Geol. Rundsch., 70, 725-736.

Frank, M., N. Whiteley, S. Kasten, J. R. Hein, and K. O'Nions (2002), North Atlantic Deep Water export to the Southern Ocean over the past $14 \mathrm{Myr}$ : Evidence from $\mathrm{Nd}$ and $\mathrm{Pb}$ isotopes in ferromanganese crusts, Paleoceanography, 17(2), 1022, doi:10.1029/2000PA000606.

Gagan, M., L. Ayliffe, D. Hopley, J. Cale, G. Mortimer, J. Chappell, M. McCulloch, and M. Head (1998), Temperature and surface ocean water balance of the mid-Holocene tropical western Pacific, Science, 279, 1014 1018

Gregory-Wodzicki, K. M. (2000), Uplift history of the central and northern Andes: A review, Geol. Soc. Am. Bull., 112, 1091-1105.

Harris, S., and A. C. Mix (2002), Climate and tectonic influences on continental erosion in tropical South America, Geology, 30, 447450.

Haug, G. H., and R. Tiedemann (1998), Effect of the formation of the Isthmus of Panama on Atlantic Ocean thermohaline circulation, Nature, 393, 673-676.

Haug, G. H., R. Tiedemann, R. Zahn, and A. C. Ravelo (2001a), Role of Panama uplift on oceanic freshwater balance, Geology, 29 , 207-210.

Haug, G. H., K. A. Hughen, D. M. Sigman, L. C. Peterson, and U. Röhl (2001b), Southward migration of the Intertropical Convergence Zone through the Holocene, Science, 293, $1304-1308$.

Hay, W. W. (1996), Tectonics and climate, Geol. Rundsch., 85, 409-437.

Hellweger, F. L., and A. L. Gordon (2002), Tracing Amazon River water into the Caribbean Sea, J. Mar. Res., 60(4), 537-549.

Hemleben, C., and M. Spindler (1983), Recent advances in research on living planktonic foraminifera, in Reconstruction of Marine Paleoenvironments, edited by J. E. Meulenkamp, Utrecht Micropaleontol. Bull., 30, 141-170.

Hoorn, C., J. Guerrero, G. A. Sarmiento, and M. A. Lorente (1995), Andean tectonics as a cause for changing drainage patterns in Miocene South America, Geology, 23, 237-240.

Hovan, S. A. (1995), Late Cenozoic atmospheric circulation intensity and climatic history recorded by aeolian deposition in the eastern equatorial Pacific, Leg 138, Proc. Ocean Drill. Program Sci. Results, 138, 615-625.

Huber, M., and R. Caballero (2003), Eocene El Niño: Evidence for robust tropical dynamics in the "hothouse", Science, 299, 877-881.

Huber, M., and L. C. Sloan (2001), Heat transport, deep waters, and thermal gradients: Coupled simulation of an Eocene greenhouse climate, Geophys. Res. Lett., $28,3481-3484$

Huber, M., L. C. Sloan, and C. Shellito (2003), Early Paleogene oceans and climate: A fully coupled modelling approach using NCAR's CSM, in Causes and Consequences of Globally Warm Climates in the Early Paleogene, edited by S. L. Wing et al., Spec. Pap. Geol. Soc. Am., 369, 25-47.

Hut, G. (1987), Stable isotope reference samples for geochemical and hydrological investigations, report to the Director General, $42 \mathrm{pp}$. Int. At. Energy Agency, Vienna.

Johns, W. E., T. L. Townsend, D. M. Fratantoni, and W. D. Wilson (2002), On the Atlantic inflow to the Caribbean Sea, Deep Sea Res. Part I, 49, 211-243.

Jousaumme, S., R. Sadourny, and C. Vignal (1986), Origin of precipitating water in a numerical simulation of the July climate, Ocean Air Interact., 1, 43-56.

Kameo, K., and T. J. Bralower (2000), Neogene calcareous nannofossil biostratigraphy of sites 998, 999, and 1000, Caribbean Sea, Proc. Ocean Drill. Program Sci. Results, 165, 3-17.

Keigwin, L. D. (1982), Isotopic paleoceanography of the Caribbean and east Pacific: Role of Panama uplift in late Neogene time, Science, 217, 350-352

Keller, G., and J. A. Barron (1983), Paleoceanographic implications of Miocene deep-sea hiatuses, Geol. Soc. Am. Bull., 94, 590-613.

Kemle-von-Mücke, S., and H. Oberhänsli (1999), The distribution of living planktic foraminifera in relation to southeast Atlantic oceanography, in Use of Proxies in Paleoceanography: Examples From the South Atlantic, edited by G. Fischer and G. Wefer, pp. 91-115, Springer, New York

King, T. A., W. G. Ellis Jr., D. W. Murray, N. J. Shackleton, and S. Harris (1997), Miocene evolution of carbonate sedimentation at the Ceara Rise: A multivariate data/proxy approach, Proc. Ocean Drill. Program Sci. Results, 154, 349-365.

Klocker, A., M. Prange, and M. Schulz (2005), Testing the influence of the Central American Seaway on orbitally forced Northern Hemisphere glaciation, Geophys. Res. Lett., 32, L03703, doi:10.1029/2004GL021564.

Kroon, D., T. V. Williams, C. Pirmez, S. Spezaferri, T. Sato, and J. D. Wright (2000), Coupled biocyclostratigraphy of site 1006: Evidence for orbitally induced carbonate platform production during the Mio- and Pliocene, Proc. Ocean Drill. Program Sci. Results, 166 155-166.

Kutzbach, J. E., and P. J. Guetter (1986), The influence of changing orbital parameters and surface boundary conditions on climate simulations for the past 18,000 years, J. Atmos. Sci., 43(16), 1726-1759.

Larsen, J. C. (1992), Transport and heat flux of the Florida Current at $27^{\circ} \mathrm{N}$ derived from the cross-steam voltages and profiling data: Theory and observation, Philos. Trans. R. Soc. London, $338,169-236$

Laskar, J., F. Joutel, and F. Boudin (1993), Orbital, precessional, and insolation quantities for the Earth from $-20 \mathrm{Myr}$ to $+10 \mathrm{Myr}$, Astron. Astrophys., 270, 522-533.

Leaman, K. D., P. S. Vertes, L. P. Atkinson, T. N. Lee, P. Hamilton, and E. Waddell (1995), Transport, potential vorticity, and current/temperature structures across Northwest Providence and Santaren Channels and the Florida Current off Cay Sal Bank, J. Geophys. Res., $100,8561-8570$.

Lear, C. H., Y. Rosenthal, and J. D. Wright (2003), The closing of a seaway: Ocean water masses and global climate change, Earth Planet. Sci. Lett., 210, 425-437. 
Levitus, S., and T. P. Boyer (1994), World Ocean Atlas 1994, vol. 4, Temperature, NOAA Atlas NESDIS, vol. 4, 99 pp., NOAA, Silver Spring, Md.

Levitus, S., R. Burgett, and T. P. Boyer (1994), World Ocean Atlas 1994, vol. 3, Salinity, NOAA Atlas NESDIS, vol. 3, 99 pp., NOAA, Silver Spring, Md.

Lisiecki, L. E., and M. E. Raymo (2005), A Pliocene-Pleistocene stack of 57 globally distributed benthic $\delta^{18} \mathrm{O}$ records, Paleoceanography, 20, PA1003, doi:10.1029/2004PA001071.

Lohmann, G. P. (1995), A model for variations in the chemistry of planktonic foraminifera due to secondary calcification and selective dissolution, Paleoceanography, 10, 445-457.

Maier-Reimer, E., U. Mikolajewicz, and K. Hasselmann (1990), Ocean general circulation model sensitivity experiments with an open Central American Isthmus, Paleoceanography, 5, 349-366.

Marshall, L. G. (1988), Land mammals and the great American interchange, $\mathrm{Am}$. Sci., 76, 380-388

McGlone, M., A. P. Kirshaw, and V. Margraf (1992), El Niño/Southern Oscillation climatic variability in Australasian and South American paleoenvironmental records, in El Niño: Historical and Paleoclimatic Aspects of the Southern Oscillation, edited by H. Diaz and V. Margraf, pp. 435-462, Cambridge Univ. Press, New York.

McIntyre, A., W. Ruddiman, K. Karlin, and A. C. Mix (1989), Glacial North Atlantic 18,000 years ago: A CLIMAP reconstruction, in Investigations of Late Quaternary Paleoceanography and Paleoclimatology, edited by $\mathrm{H}$. J. Cline et al., pp. 43-76, Geol. Soc. of Am., Boulder, Colo.

Mikolajewicz, U., and T. J. Crowley (1997), Response of a coupled ocean/energy balance model to restricted flow through the Central American Isthmus, Paleoceanography, 12, $429-441$

Mix, A. C., and W. F. Ruddiman (1984), Oxygen-isotope analyses and Pleistocene ice volumes, Quat. Res., 21, 1-20.

Mix, A. C., N. G. Pisias, W. Rugh, J. Wilson, A. Morey, and T. K. Hagelberg (1995), Benthic foraminifer stable isotope record from site 849 (0-5 Ma): Local and global climate changes, Proc. Ocean Drill. Program Sci. Results, 138, $371-412$.

Mix, A. C., et al. (2003), Proceedings of the Ocean Drilling Program Initial Report, vol. 202, Ocean Drill. Program, College Station, Tex.

Molinari, R., E. Johns, and J. F. Festa (1990), The annual cycle of meridional heat flux in the Atlantic Ocean at $26.5^{\circ} \mathrm{N}, J$. Phys. Oceanogr., 20, 476-482.

Molnar, P., and M. A. Cane (2002), El Niño's tropical climate and teleconnections as a blueprint for pre-Ice Age climates, Paleoceanography, 17(2), 1021, doi:10.1029/2001PA000663.

Montgomery, D. R., G. Balco, and S. D. Willett (2001), Climate, tectonics, and the morphology of the Andes, Geology, 29, 579-582.

Mulitza, S., B. Donner, G. Fischer, A. Paul, J. Pätzold, C. Rühlemann, and M. Segl (2004), The South Atlantic oxygen-isotope record of planktic foraminifera, in The South Atlantic in the Late Quaternary: Reconstruction of Mass Budget and Current Systems, edited by G. Fischer and G. Wefer, pp. 121-142, Springer, New York.

Müller-Karger, F. E., C. R. McClain, T. R. Fisher, W. E. Esaias, and R. Varela (1989), Pigment distribution in the Caribbean Sea: Observations from space, Prog. Oceanogr., 23, 23-64.

Niebler, H.-S., H.-W. Hubberten, and R. Gersonde (1999), Oxygen isotope values of planktic foraminifera: A tool for the reconstruction of surface water stratification, in Use of Proxies in Paleoceanography, edited by G. Fischer and G. Wefer, pp. 165-189, Springer, New York.

Nisancioglu, K. H., M. E. Raymo, and P. H. Stone (2003), Reorganization of Miocene deep water circulation in response to the shoaling of the Central American Seaway, Paleoceanography, 18(1), 1006, doi:10.1029/2002PA000767. Nof, D., and S. van Gorder (2003), Did an open Panama Isthmus correspond to an invasion of Pacific water into the Atlantic?, J. Phys. Oceanogr., 33, 1324-1336

Norris, R. D. (1998), Miocene-Pliocene surface water hydrography of the eastern equatorial Atlantic, Proc. Ocean Drill. Program Sci. Results, 159, 539-555.

Nürnberg, D. (2000), Taking the temperature of past ocean surfaces, Science, 289, 1698-1699.

Nürnberg, D., J. Bijma, and C. Hemleben (1996), Assessing the reliability of magnesium in foraminiferal calcite as a proxy for water mass temperatures, Geochim. Cosmochim. Acta, 60, 803-814.

Nürnberg, D., A. Müller, and R. Schneider (2000), Paleo-sea surface temperature estimations in the equatorial east Atlantic from $\mathrm{Mg}$ Ca ratios in planktic foraminifers: A comparison to SST estimates from $\mathrm{U}_{37}^{K^{\prime}}$, oxygen isotopes, and foraminiferal transfer function, Paleoceanography, 15, 124-134.

Nürnberg, D., et al. (2002), Rapid climate changes in the western tropical AtlanticAssessment of the biogenous and sedimentary record, $R / V$ Sonne Cruise Rep. SO 164 151 pp., GEOMAR, Kiel, Germany.

O'Neil, J. R., R. N. Clayton, and T. K. Mayeda (1969), Oxygen isotope fractionation in divalent metal carbonates, J. Chem. Phys., 51, $5547-5558$

Ottens, J. J. (1992), Spatial dynamics of planktic foraminifera in the northeast Atlantic, in Planktonic Foraminifera as Indicators of Ocean Environments in the Northeastern Atlantic, edited by J. J. Ottens, pp. 109-147, Acad. Proefschr., Vrije Univ. Amsterdam, Amsterdam.

Paillard, D., L. Labeyrie, and P. Yiou (1996), Macintosh program performs time-series analysis, Eos Trans. AGU, 77, 379.

Peltier, W. R., and L. P. Solheim (2004), The climate of the Earth at Last Glacial Maximum: Statistical equilibrium state and a mode of internal variability, Quat. Sci. Rev., 23, 335357.

Philander, S. G. H. (1990), El Niño, La Niña and the Southern Oscillation, 293 pp., Academic, Elsevier, New York.

Philander, S. G. H., and A. V. Fedorov (2003), Role of tropics in changing the response to Milankovich forcing some three million years ago, Paleoceanography, 18(2), 1045 , doi:10.1029/2002PA000837

Philander, S. G. H., and R. C. Pacanowski (1986) A model of the seasonal cycle in the tropical Atlantic, J. Geophys. Res., 91, 14,192-14,206.

Philander, S. G. H., D. Gu, D. Halpern, G. Lambert N. C. Lau, T. Li, and R. C. Pacanowski (1996), Why the ITCZ is mostly north of the equator, J. Clim., 9, 2958-2972.

Prange, M. (2006), The low-resolution CCSM2 revisited: Adjustments and a present-day control run, Ocean Sci. Discuss., 3, $1293-$ 1348
Prange, M., and M. Schulz (2004), A coastal upwelling seesaw in the Atlantic Ocean as a result of the closure of the Central American Seaway, Geophys. Res. Lett., 31, L17207, doi:10.1029/2004GL020073

Raffi, I., and J. A. Flores (1995), Pleistocene through Miocene calcareous nannofossils from the eastern equatorial Pacific Ocean (Leg 138), Proc. Ocean Drill. Program Sci. Results, 138 233-282.

Raymo, M. E., B. Grant, M. Horowitz, and G. H. Rau (1996), Mid-Pliocene warmth: Stronger greenhouse and stronger conveyor, Mar Micropaleontol., 27, 313-326.

Reuning, L. (2005), The origin of subMilankovitch cycles in early Pliocene carbonate platform sediment: Bahamas vs. Maldives, Ph.D. thesis, 114 pp., Univ. of Kiel, Kiel, Germany

Reuning, L., J. J. G. Reijmer, C. Betzler, P. Swart, and T. Bauch (2005), The use of paleoceanographic proxies in carbonate periplatform settings - Opportunities and pitfalls, Sediment. Geol., 175, 131-152.

Reuning, L., J. J. G. Reijmer, C. Betzler, A. Timmermann, and S. Steph (2006), SubMilankovitch cycles in periplatform carbonates from the early Pliocene Great Bahama Bank, Paleoceanography, 21, PA1017, doi:10.1029/ 2004PA001075.

Rodbell, D. T., G. O. Seltzer, D. M. Andreson, M. A. Abbott, D. B. Enfield, and J. H. Newman (1999), An 15,000 year record of El Niñodriven alluviation in southwestern Ecuador, Science, 283, 516-520.

Savin, S. M., and R. G. Douglas (1985), Sea level, climate, and the Central American Land Bridge, in The Central American Land Bridge, edited by F. G. Stehli and S. D. Webb, pp. 303-324, Springer, New York.

Schmuker, B., and R. Schiebel (2002), Planktic foraminifers and hydrography of the eastern and northern Caribbean Sea, Mar. Micropaleontol., 46, 387-403.

Schott, F. A., T. N. Lee, and R. Zantopp (1988), Variability of structure and transport of the Florida Current in the period range of days to seasonal, J. Phys. Oceanogr., 18, 12091230.

Shackleton, N. J. (1974), Attainment of isotopic equilibrium between ocean water and the benthonic foraminifera genus Uvigerina: Isotopic changes in the ocean during the las glacial, Colloq. Int. C. N. R. S, 219, 203-210.

Shackleton, N. J., and M. A. Hall (1984), Oxygen and carbon isotope stratigraphy of Deep Sea Drilling Project Hole 552A: Plio-Pleistocene glacial history, Initial. Rep. Deep Sea Drill. Proj., 81, 599-629.

Shackleton, N. J., and M. A. Hall (1997), The late Miocene stable isotope record, site 926 , Proc. Ocean Drill. Program Sci. Results, 154, 367-373.

Shackleton, N. J., M. A. Hall, and D. Pate (1995), Pliocene stable isotope stratigraphy of site 846, Proc. Ocean Drill. Program Sci. Results, 138, 337-353.

Sigurdsson, H., et al. (1997), Proceedings of the Ocean Drilling Program Initial Report, vol. 165, Ocean Drill. Program, College Station, Tex

Spero, H. J., K. M. Mielke, E. M. Kalve, D. W. Lea, and D. K. Pak (2003), Multispecies approach to reconstructing eastern equatorial Pacific thermocline hydrography during the past 360 kyr, Paleoceanography, 18(1), 1022, doi:10.1029/2002PA000814

Steph, S. (2005), Pliocene stratigraphy and the impact of Panama uplift on changes in Carib- 
bean and tropical east Pacific upper ocean stratification $(6-2.5 \mathrm{Ma})$, Ph.D. thesis, $158 \mathrm{pp}$., Univ. of Kiel, Kiel, Germany.

Steph, S., R. Tiedemann, J. Groeneveld, A. Sturm, and D. Nürnberg (2006), Pliocene changes in tropical east Pacific upper ocean stratification: Response to tropical gateways?, Proc. Ocean Drill. Program Sci. Results, 202, 1-51, doi:10.2973/odp.proc.sr.202.211.2006.

Tiedemann, R., and S. O. Franz (1997), Deepwater circulation, chemistry, and terrigenous sediment supply in the equatorial Atlantic during the Pliocene, 3.3-2.6 Ma and 5-4.5 Ma, Proc. Ocean Drill. Program Sci. Results, 154, 299-318.

Tiedemann, R., M. Sarnthein, and R. Stein (1989), Climatic changes in the western Sahara: Paleo-marine sediment record of the last 8 million years (sites 657-661), Proc. Ocean Drill. Program Sci. Results, 108, 241-277.

Tiedemann, R., M. Sarnthein, and N. J. Shackleton (1994), Astronomic timescale for the Pliocene Atlantic $\delta^{18} \mathrm{O}$ and dust flux records of Ocean Drilling Program site 659, Paleoceanography, 9, 619-638.

Tiedemann, R., et al. (2006), Astronomically calibrated timescales from 6 to $2.5 \mathrm{Ma}$, and benthic isotope stratigraphies of sites 1236 , 1237, 1239, and 1241, Ocean Drill. Program Sci. Results, in press.
Tudhope, A. W., C. P. Chilcott, M. T. McCulloch, E. R. Cook, J. Chappell, R. M. Ellam, D. W. Lea, J. M. Lough, and G. B. Shimmield (2001), Variability in the El Niño-Southern Oscillation through a glacial-interglacial cycle, Science, 291, 1511-1516.

Von der Heydt, A., and H. A. Dijkstra (2006), Effect of ocean gateways on the global ocean circulation in the late Oligocene and early Miocene, Paleoceanography, 21, PA1011, doi:10.1029/2005PA001149.

Wang, D. (2001), A note on using the accelerated convergence method in climate models, Tellus Ser. A, 53, 27-34.

Webb, S. D. (1985), Late Cenozoic mammal dispersals between the Americas, in The Great American Biotic Interchange, edited by F. G. Stehli and S. D. Webb, pp. 357-386, Springer, New York.

Whitehead, J. M., and S. M. Bohaty (2003), Pliocene summer sea surface temperature reconstruction using silicoflagellates from Southern Ocean ODP Site 1165, Paleoceanography, 18(3), 1075, doi:10.1029/2002PA000829.

Woodruff, F., and S. Savin (1989), Miocene deepwater oceanography, Paleoceanography, 4, $87-140$

Wright, J. D., and K. G. Miller (1996), Control of North Atlantic Deep Water circulation by the Greenland-Scotland Ridge, Paleoceanography, 11, 157-170.
Wüst, G. (1964), Stratification and Circulation in the Antillean-Caribbean Basins, Part 1 Spreading and Mixing of the Water Types With an Oceanographic Atlas, Columbia Univ. Press, New York.

Yoshimori, M., T. F. Stocker, C. C. Raible, and M. Renold (2005), Externally forced and internal variability in ensemble climate simulations of the Maunder Minimum, J. Clim., 18, 42534270

J. Groeneveld, M. Prange, and M. Schulz, Deutsche Forschungsgemeinschaft Research Center Ocean Margins, University of Bremen, Klagenfurter Straße, D-28334 Bremen, Germany.

G. H. Haug, GeoForschungsZentrum Potsdam, Telegrafenberg, D-14473 Potsdam, Germany.

D. Nürnberg, Leibniz Institute of Marine Sciences, IFM-GEOMAR, Wischhofstraße 1-3, D-24148 Kiel, Germany.

L. Reuning, Institute of Geology, RheinischWestfälische Technische Hochschule Aachen, Wüllnerstraße 2, D-52062 Aachen, Germany.

S. Steph and R. Tiedemann, Alfred Wegener Institute for Polar and Marine Research, Columbusstraße, D-27568 Bremerhaven, Germany. (ssteph@awi-bremerhaven.de) 